DEPARTMENT OF THE INTERIOR

U.S. GEOLOGICAL SURVEY

\title{
Pedological studies at Grays Landing terrace, Fayette County, Pennsylvania
}

by

Robert B. Jacobson

Open-File Report 87-128

Prepared in cooperation with U.S. Army Corps of Engineers

This report is preliminary and has not been reviewed for conformity with U.S. Geological Survey editorial standards. 


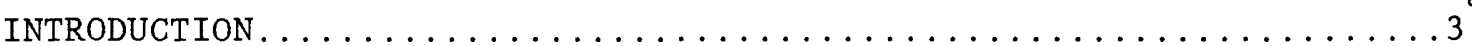

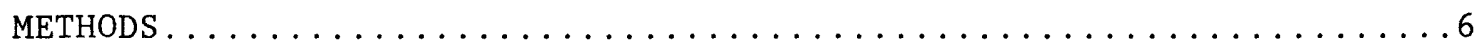

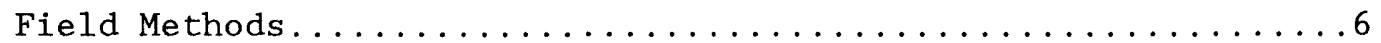

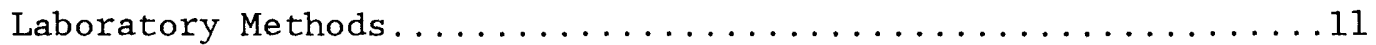

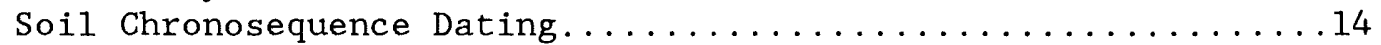

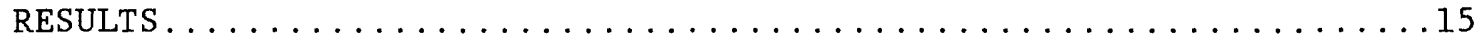

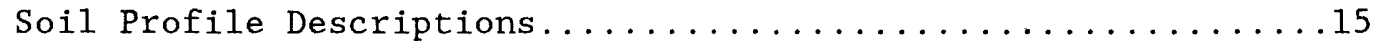

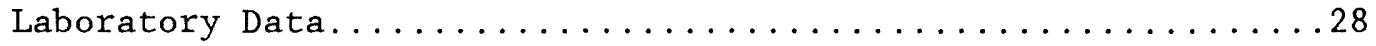

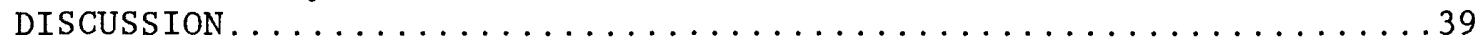

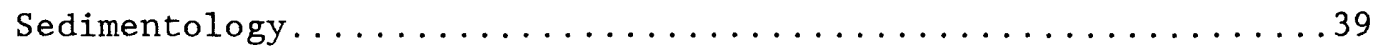

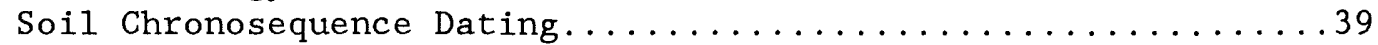

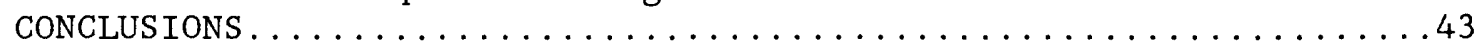

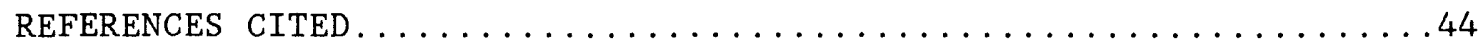

\section{ILLUSTRATIONS}

Figure $1 . \quad$ Locality map.........................

2. Detailed map of Grays Landing sample locations........5

3. Standard U.S.D.A. textural classes...............13

4. Reproducibility of particle-size method...........13

5. Particle size data for test-pit soil profiles......31-33

6. Clay and extractable $\mathrm{Fe}_{2} \mathrm{O}_{3}$ plotted by depth, TP $10 \ldots 36$

7. X-ray diffraction traces, TP $10 \ldots \ldots \ldots \ldots \ldots$

8. Si, Al and $15 \mathrm{~A}: 10 \mathrm{~A}$ diffraction peaks

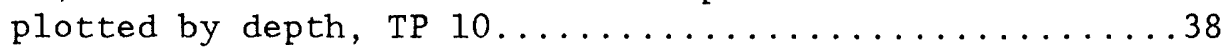

9. Particle size of Grays Landing data compared to

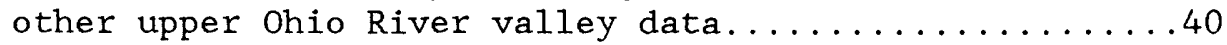

10. Accumulated clay plotted against soil age.........42

\section{TABLES}

Table 1. Particle size and bulk density data............29-30

2. CBD-extractable oxides and x-ray diffraction data, TP 10..35 


\section{INTRODUCTION}

The United States Army Corps of Engineers plans to build a navigation lock and dam in the vicinity of River Mile 82 of the Monongahela River, in southwestern Pennsylvania (fig. 1). The lock and dam structure and accompanying construction activities will disrupt the surface of a prominent terrace deposit which extends from approximately River Mile 81 to River Mile 83 along the right bank of the river (Fig 2). The terrace depositional surface is approximately 244-245 m (800-805 ft) a.s.1. (above sea level), or $11.3-12.8 \mathrm{~m}$ (37-42 ft) above present normal pool level of the river.

This report presents results of a study of the sedimentology and pedogenesis of the terrace deposit. The study was conducted as part of a comprehensive investigation of the stratigraphy, sedimentology, and geologic history of the terrace in order to evaluate its archeological resource potential. Specifically, the investigation was intended to evaluate the probability that horizons of cultural occupation are buried within the deposit. The comprehensive investigation was directed by James V. Hamel of Hamel Geotechnical Consultants, Monroeville, Pa.; the entire report is on file with the Planning Division, Pittsburgh District U.S. Army Corps of Engineers.

Two archeological questions provided context for the investigation. First, was the terrace deposit formed during a time period when native Americans are known to have been inhabiting the Monongahela River valley? For the purposes of this study, the earliest date of occupation was assumed to be approximately 17,000 yr B.P. (Adovasio and others, 1983). Second, do the sedimentology and stratigraphy of the deposit indicate a favorable environment for human habitation?. This question is especially important for the Monongahela River valley because of its history of periodic ponding during Pleistocene ice advances; it is assumed that occupation horizons would be more likely to be found in alluvial overbank deposits than in lacustrine deposits.

Five of the twenty-six total test pits excavated were chosen for the detailed study reported here. The five test pits were chosen in order to obtain a representative sample of sedimentological and soil-forming environments. Detailed work on these test pits was intended to, a) provide quantitative sedimentological data on the silty and fine-sand sediments that blanket the terrace to depths of 4-7 m (13-21 ft), and b) constrain the age of the deposit based on the degree of weathering and pedogenesis. 


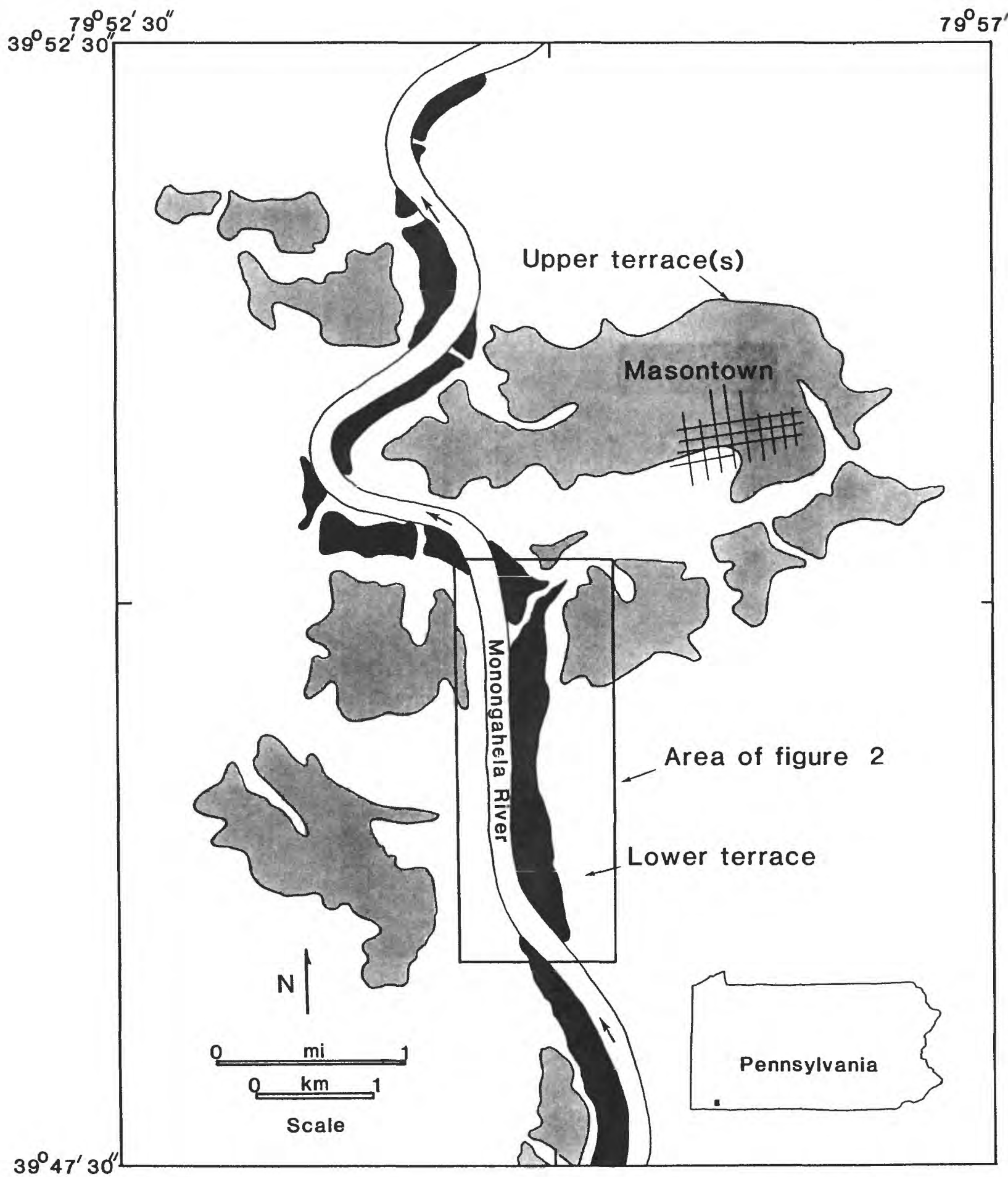

Figure 1. Locality map showing the Grays Landing terrace and correlated terraces (Low terrace, dark shading), and remnants of early-to-middle pleistocene-age terraces (Upper terrace(s), light shading). 


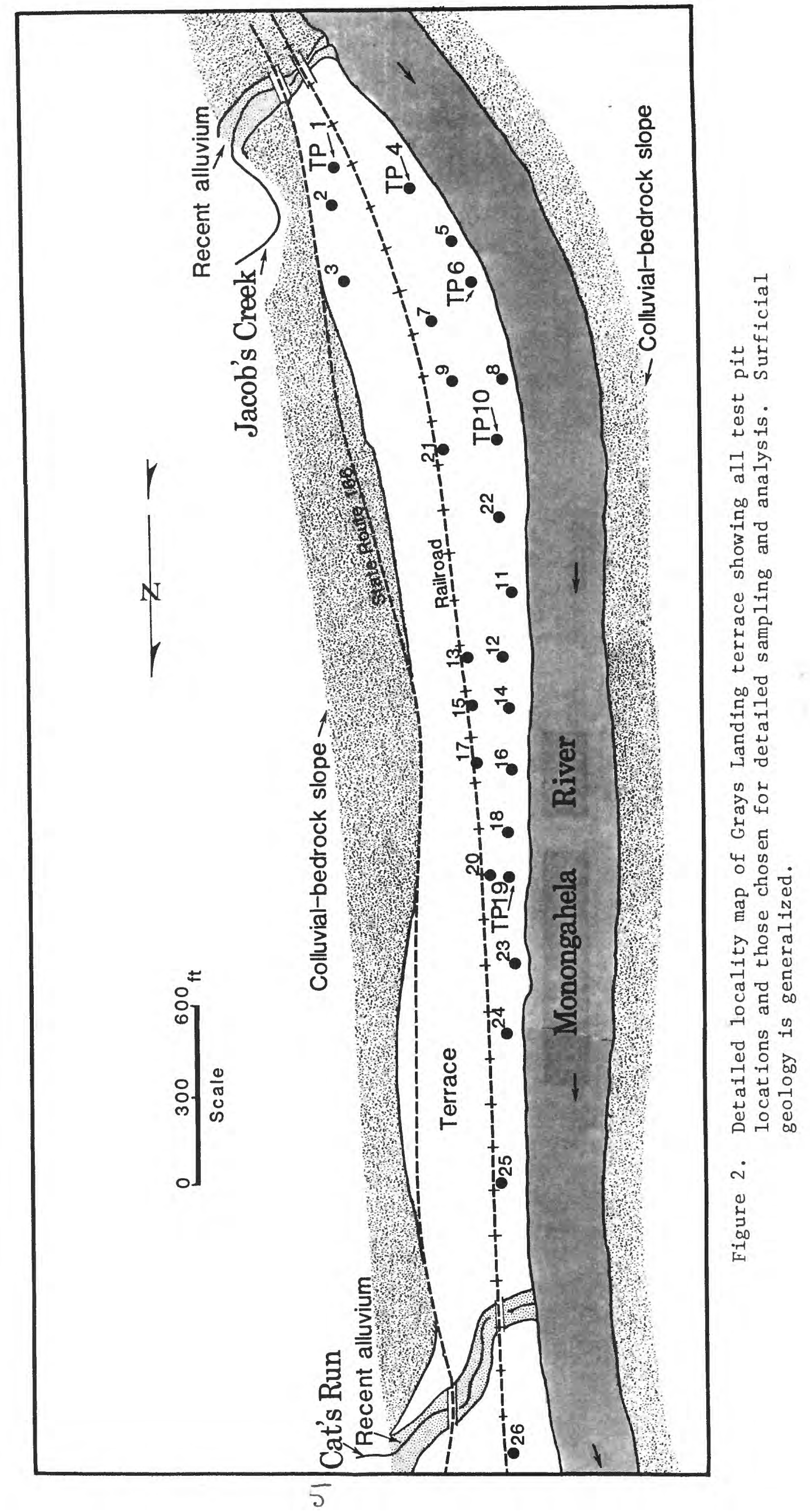




\section{METHODS}

\section{Field Methods}

The following elements are used in the attached soil profile descriptions. The descriptions are based on standard methods used by the U.S. Department of Agriculture (1951 and revisions); however, some alterations have been made to emphasize the geologic aspects of the soil descriptions. These modifications are based partly on suggestions made by Birkeland (1974). It should be emphasized that, although a standard format is used, departures from the standard format are necessary, and desirable, to include all the complexity of a given soil profile.

Soil profile description elements

1. Horizon designation: Following U.S.D.A. (1951 and revisions).

2. Depth: Top and bottom of horizon.

3. Color: Munsel1 (1975) descriptive term with numerical term following in parentheses. If mottling dominates the horizon color, mottling is described here. If mottling is of less important, it is described in element 11.

4. Texture: U.S.D.A. designations on triangular diagram, fig. 3. The following abbreviations, descriptions, and field criteria apply:

\begin{tabular}{lc}
$\frac{\text { Name }}{\text { Sand }}$ & \multicolumn{2}{c}{ Abbreviation } \\
Loamy Sand & LS \\
Sandy Loam & SL \\
Loam & L \\
Silt Loam & Sil \\
Silt & Si \\
Sandy Clay Loam & SCL \\
& \\
Clay Loam & CL \\
Silty Clay Loam & SiCL \\
Sandy Clay & SC \\
Silty Clay & SiC \\
Clay & C
\end{tabular}

\section{Field criteria \\ Loose grains; crumbles; can't form} cast when squeezed in hand.

Crumbles; can't form cast; leaves hands dirty.

Moderately durable, moist cast; can't form ribbon when squeezed out between thumb and finger.

Gritty to smooth; forms moist cast; can't form ribbon.

Grit is evident but soft and floury; forms cast; can't form ribbon. Floury, no grit; forms ribbon. Forms a wire when rolled on palm; wire easily broken; some grit evident.

Forms wire, easily broken, little grit evident.

Forms wire, easily broken, no grit.

Forms durable wire, sandy grit evident.

Forms durable wire, no grit.

Very plastic; forms long, thin, durable wire; no grit.

Field texture tests are performed on soil fraction with particle size of less than $2 \mathrm{~mm}$ (fine earth fraction), and textural terms are modified 
with descriptors such as cobbly, channery, gravelly, etc. Sand terms may be modified by very fine, fine, medium, etc.

5. Soil structure: Characteristics of soil aggregates (peds). Three terms are used: grade, size, type. Subsidiary structure can be described by compounding terms, e.g.: moderate, medium, prismatic breaking to strong, fine, angular blocky.

Grade:

Massive
Single grain

Weak

Moderate

Strong

Size:

$\begin{array}{ll} & \frac{\text { Platy }}{<1 \mathrm{~mm}} \\ \text { very fine } & 1-2 \\ \text { fine } & 2-5 \\ \text { medium } & 5-10 \\ \text { coarse } & >10 \mathrm{~mm} \\ \text { very coarse } & \end{array}$

Type:

Platy
Prismatic
Blocky
Granular

Granular
Coherent, no aggregation into structural units.

Non-coherent, no aggregation into structural units.

Barely observable aggregation in situ; when broken out and handled, many peds break into single grains or sub-units.

Evident in situ; moderately durable when broken out and handled; some break into sub units.

Distinct in situ; durable when broken out.

$$
\begin{aligned}
& \frac{\text { Blocky }}{<5 \mathrm{~mm}} \\
& 5-10 \\
& 10-20 \\
& 20-50 \\
& >50 \mathrm{~mm}
\end{aligned}
$$

\begin{tabular}{l} 
Granular \\
\hline$<1 \mathrm{~mm}$ \\
$1-2$ \\
$2-5$ \\
$5-10$ \\
$>10 \mathrm{~mm}$
\end{tabular}

Horizontal planar forms.

Forming vertical or subvertical prisms or columns.

Point-centered polyhedra: subangular or angular.

Forming quasi-spheroidal crumbs.

6. Consistence: Strength and nature of inter-particle forces. Consistence can be described at three different moisture contents, wet, moist (field capacity), or dry. Moist consistence is considered minimum for a profile description.

Wet: Described near plastic limit. Two properties, stickiness and plasticity, are described.

Stickiness: tested between thumb and forefinger.

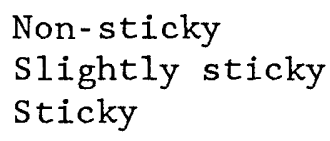

Very sticky
No adhesion to fingers.

Some adhesion to fingers, easily removed. Adhesion to fingers, soil stretches slightly.

Strong adhesion to fingers, soil stretches before pulling away. 
Plasticity: soil rolled into $2-4 \mathrm{~mm}$ diameter wire on palm of hand.

Non-plastic

S1ightly plastic

Plastic

Very plastic
No wire can be formed.

Wire forms, easily crumbled.

Long, thin wire forms; cast will deform under moderate pressure.

Long, thin, durable wire; cast deforms only under much pressure.

Moist: Performed at or near field capacity (i.e., freely-drained moisture content).

Loose
Very friable
Friable
Firm
Very firm
Extremely firm

Dry: Described in air-dry state.
Non coherent

Crushes under gentle pressure between thumb and forefinger.

Crushes under gentle to moderate pressure.

Crushes under moderate pressure with some resistance.

Strong pressure needed to crush, barely possible with thumb and finger.

Not possible to crush with thumb and forefinger.

\author{
Loose \\ Soft \\ S1ightly hard \\ Hard \\ Very hard \\ Extremely hard
}

Non-coherent

Powders with slight pressure.

Easily broken between thumb and forefinger.

Moderate resistance to breakage; barely breakable with finger and thumb;

easily broken in two hands.

Very resistant; not breakable with fingers; break in hands with difficulty. Cannot be broken with hands.

7. Cementation: Cementation agent identified if possible and grade of cementation as:

Weakly cemented

Strongly cemented

Indurated
Brittle and breakable by hand.

Not breakable by hand; can break with hammer.

Hammer rings; material does not soften with wetting. 
8. Clay films: Frequency, thickness and morphology required; color, mottles and other features can be added.

Frequency: percentage of ped face or pores that have films.

$\begin{array}{ll}\text { Very few } & <58 \\ \text { Few } & 5-25 \% \\ \text { Common } & 25-508 \\ \text { Many } & 50-90 \% \\ \text { Continuous } & 90-1008\end{array}$

Thickness:

Thin

Moderately thick

Thick
Very fine sand grains stick out through films.

Very fine sand grains are covered and indistinct.

Fine sand grains are coated, indistinct; films visible without magnification.

Morphology: where films occur.
Ped faces
Bridging grains
Pore linings
Waves, lamellae
Coats on clasts

9. Notes on coarse fraction clasts: Including size, shape, sorting, sedimentological characteristics, and lithology. Size classes conform to a modified version of Wentworth's (1922) scale:

$\begin{array}{ll}\text { Pebbles } & 0.2-6.4 \mathrm{~cm} \\ \text { Cobbles } & 6.4-25.6 \mathrm{~cm} \\ \text { Boulders } & >25.6 \mathrm{~cm}\end{array}$

10. Roots: Estimated number per square decimeter for various size classes.

\begin{tabular}{|c|c|c|c|c|}
\hline & very fine & fine & medium & coarse \\
\hline & $<1 \mathrm{~mm}$ & $1-2 \mathrm{~mm}$ & $2-5 \mathrm{~mm}$ & $5-10 \mathrm{~mm}$ \\
\hline few & $<10$ & $<10$ & $<1$ & $<1$ \\
\hline common & $10-100$ & $10-100$ & $1-10$ & $1-5$ \\
\hline many & $>100$ & $>100$ & $>10$ & $>5$ \\
\hline
\end{tabular}

11. Mottles: Abundance, size, and contrast with color. Same format used for concretions.

Abundance:

Few

Common

Many
$<28$ of surface area

$2-20 \%$ of surface area

$>208$ of surface area 
Size:

$\begin{array}{ll}\text { Fine } & <5 \mathrm{~mm} \text { diameter } \\ \text { Medium } & 5-15 \mathrm{~mm} \text { diameter } \\ \text { Coarse } & >15 \mathrm{~mm} \text { diameter }\end{array}$

Contrast:

Faint Seen only with close examination.

Distinct Readily seen; mottles vary $1-2$ hues or several

Prominent $\quad$ Obvious; most outstanding feature of horizon.

12. $\mathrm{pH}$ : Measured in the lab or field in 1:1, soil:water mixture;

in standard $\mathrm{pH}$ units.

13. Horizon boundaries: Distinctiveness and topography.

Distinctiveness: based on distance over which transition occurs.

$\begin{array}{ll}\text { Very abrupt } & \text { Knife-edge contact. } \\ \text { Abrupt } & <2.5 \mathrm{~cm} \\ \text { Clear } & 2.5-6.25 \mathrm{~cm} \\ \text { Gradual } & 6.25-12.5 \mathrm{~cm} \\ \text { Diffuse } & >12.5 \mathrm{~cm}\end{array}$

Topography:

$\begin{array}{ll}\text { Smooth } & \text { Planar } \\ \text { Wavy } & \text { Undulating, pockets wider than deep. } \\ \text { Irregular } & \text { Pockets deeper than width. } \\ \text { Broken } & \text { Unconnected parts. }\end{array}$




\section{Laboratory Methods}

The following analyses were performed in the laboratory:

1). Particle size, all samples.

2). Bulk density, all samples.

3). $\mathrm{pH}$, all samples.

4). Citrate-bicarbonate-dithionite-extractable $\mathrm{Fe}$ (iron), Si (Silica), and A1 (Aluminum), TP 10.

5). X-ray diffraction analysis of the clay-size fraction, TP 10.

Particle size analysis was performed on samples with particles $>2$ $\mathrm{mm}$ and roots removed. The total-horizon sample was split into a representative subsample of approximately $20 \mathrm{~g}$. The subsample was dried to constant weight in $100^{\circ} \mathrm{C}$ oven, and weighed. Organic carbon, if present, was removed by digestion in boiling, $308 \mathrm{H}_{2} \mathrm{O}_{2}$; these samples were redried, and reweighed. An aliquot of sodium hexametaphosphate dispersant solution was added to each sample and they were shaken 12 hours on a reciprocating shaker. Samples were then wet-sieved into the fraction $>63 \mathrm{um}$ (sand sizes in microns or micrometers) and the fraction $<63 \mathrm{um}$ (silt+clay sizes). The sand-size fraction was dried and sieved ultrasonically into five fractions corresponding to $>1 \mathrm{~mm}, 1-0.5 \mathrm{~mm}$, 0.5-0.25 mm, 0.25-0.125 mm, and 0.125-0.063 mm (125 um - 63 um). These fractions correspond to $0,1,2,3$, and 4 on the phi scale. They are also approximately equal to the very coarse, coarse, medium, fine, and very fine sand fractions of the U.S.D.A. (1951) except that the U.S.D.A. fine and very fine sand fraction lower size limits are $0.1 \mathrm{~mm}$ and 0.05 $\mathrm{mm}$, respectively.

The fraction smaller than 63 um was washed into a $1000 \mathrm{ml}$ settling cylinder for pipet analysis by Stokes fall velocity. Fractions were taken at $63 \mathrm{um}$ ( $4 \mathrm{phi}), 16 \mathrm{um}$ ( $6 \mathrm{phi})$, and $2 \mathrm{um}$ ( 9 phi). Results from the sieve and pipet analyses were collected in digital data files and analyzed by computer programs. Reproducibility on eight analyses of sample 344 (including subsampling error) is shown in the ternary particle-size diagram in fig. 4. Means and standard deviations for the sand, silt, and clay fractions are:

\begin{tabular}{ccc} 
Fraction & Mean & Standard deviation \\
\cline { 2 - 3 } sand & 33.7 & 0.8 \\
silt & 46.2 & 1.0 \\
clay & 20.1 & 0.4
\end{tabular}

Bulk density was calculated by weighing hair-net-supported, saran-resin-coated clods in air and in water. Calculations are based on Archimedes' principle.

$\mathrm{PH}$ was measured in a $1: 1$ mixture of soil and de-ionized water. Measurement was with a standard $\mathrm{pH}$ electrode. Error is estimated at plus/minus $0.2 \mathrm{pH}$ units.

CBD-Fe, Si, and Al were extracted from 16 horizon samples of TP \#10 following the procedures of Mehra and Jackson (1960). This procedure removes amorphous and crystalline forms of iron oxyhydroxides, including 
ferrihydrite, goethite, and hematite, plus other amorphous and crystalline phases physically and chemically mixed with the oxyhyroxides. $\mathrm{Fe}, \mathrm{Si}$, and $\mathrm{Al}$ were assayed by inter-coupled plasma spectroscopy and results were calculated to oxide equivalences. Estimated error is plus/minus 58 relative error.

Mineralogy of the clay-particle-size fraction was analyzed by $\mathrm{x}$-ray diffraction to determine the dominant clay mineral phases. Samples were disaggregated by a combination of gentle crushing, shaking in sodium hexametaphosphate dispersant solution, and immersion in an ultrasonic bath. Amorphous iron interference was removed by the CBD-iron procedure described above, which also removes most organic material. The particle size fraction less than 2 um was separated by centrifugation and sedimented onto glass sample slides to make oriented aggregates. Samples were $x$-rayed air-dry, after solvation with ethylene glycol, after heating to $350^{\circ} \mathrm{C}$, and after heating to $550^{\circ} \mathrm{C}$. Samples were run from 40 to $2.5^{\circ}$ 2-theta, $3.2^{\circ} 2$-theta/minute, at $45 \mathrm{kV}$ and $15 \mathrm{Ma}$.

Phases were identified using methods described by Carroll (1970). The following assumptions were used:

1) Phases that swell with ethylene glycol solvation are smectites and/or mixed-layer smectites/illites.

2) Phases that collapse from 14 angstrom (A) to $10 \mathrm{~A}$ with heating to $350^{\circ} \mathrm{C}$ are vermiculites. illites.

3) Phases that maintain a $10 \mathrm{~A}$ spacing for all preparations are

4) Phases that give a $14 \mathrm{~A}$ reflection after $550^{\circ}$ treatment are chlorites. The term chlorite is used here synonymously with "soil chlorite" and "hydroxy-interlayered vermiculite".

5) Phases with 7 A spacings that disappear between $350^{\circ}$ and $550^{\circ}$ are kaolinite.

6) Quartz is identified by the 4.26 A reflection.

7) Gibbsite is identified by the $4.85 \mathrm{~A}$ reflection which is destroyed in the process of heating to $350^{\circ} \mathrm{C}$.

Diffraction patterns were analyzed qualitatively to ascertain the overall clay mineral phase assemblage and to ascertain changes in dominant clay mineral phases with depth in the profile. 

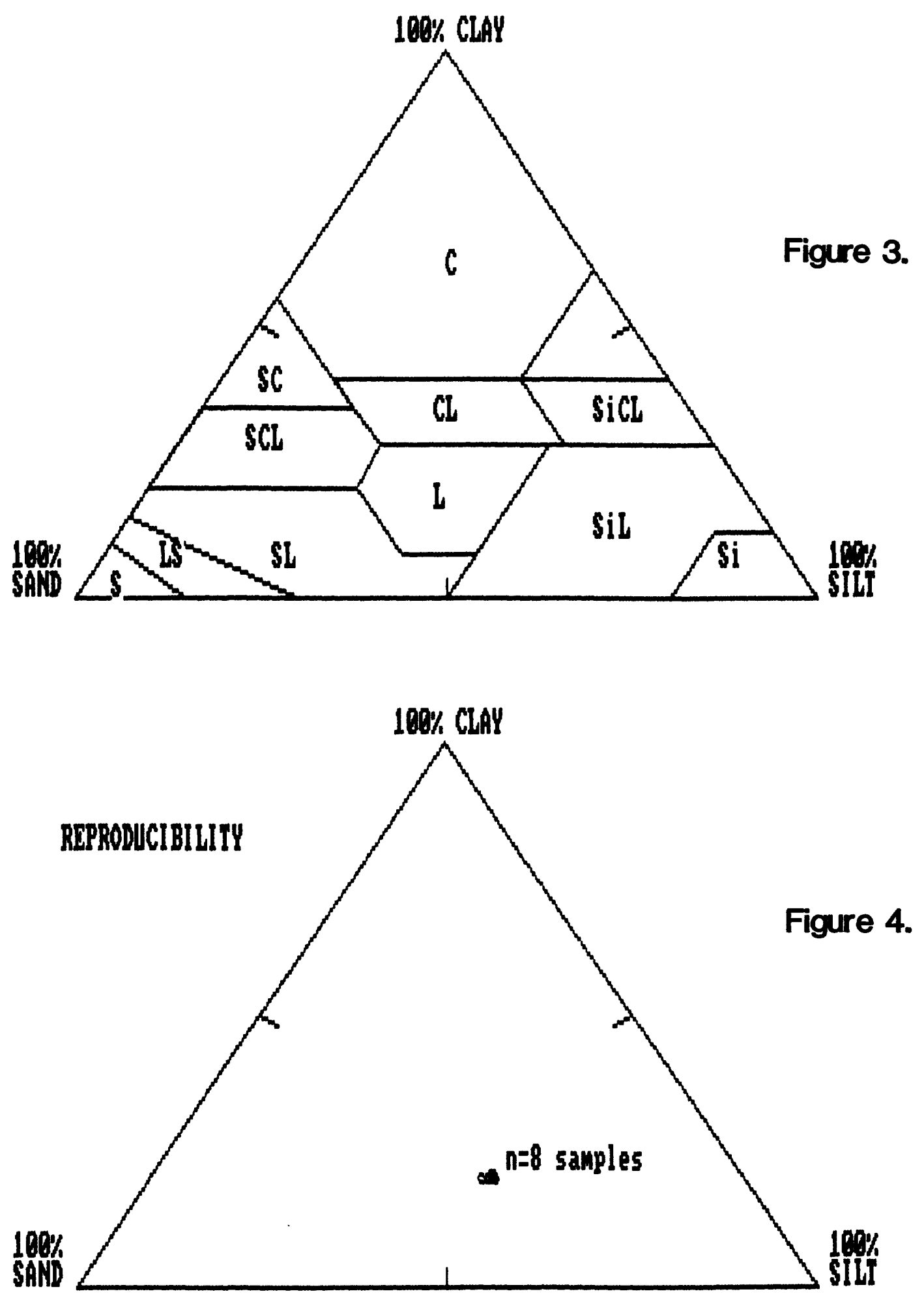

Figure 3. Standard U.S.D.A. textural classes.

Figure 4. Reproducibility of particle-size method. Results of eight replicate analyses of Grays Landing sample 344. 


\section{Soil Chronosequence Dating}

Relative, or interpolative, dating by degree of soil formation is based on the fact that once deposited, a sediment is progressively weathered. Weathering consists of the physical and chemical changes that occur within the soil body due to reorganization, additions, and losses of soil materials. Some of these processes produce measurable changes in the soil as a more-or-less orderly function of time of weathering (that is, soil age). However, the state of a soil profile is also a function of variables other than time, such as parent sediment, drainage, erosion, biological influences, and climatic influences (Jenny, 1941). These variables must be kept constant or constrained in order to isolate the effects of soil age. In addition, the chosen weathering parameter must be sufficiently sensitive over the timescale of interest that appreciable changes can be measured. Finally, because the physical processes involved are poorly understood and cannot by portrayed as analytical functions, an empirical, independently dated chronosequence is necessary for calibration.

Previous studies by the author of pedogenesis of Pleistocene-age alluvial and slackwater terrace deposits (Jacobson, 1985) provide a basis for chronosequence interpolative dating. These studies established an independently dated chronosequence of soils formed on parent materials similar to those at Grays Landing. In addition, the studies provide a basis for choosing weathering parameters that have the most promise to resolve weathering differences on the timescale of interest. 


\section{RESULTS}

\section{Soil Profile Descriptions}

Test pit \#1

Fill 0-20 cm (0-0.6 ft) (not sampled), very dark gray (5YR3/1), sand to pebble-size coal fragments in silty matrix with few, pebble-size, red $(2.5 Y R 5 / 1)$ to white $(10 Y R 8 / 1)$ carbonate-rich, slag fragments; very abrupt, wavy boundary.

308

2BA 20-31 cm (0.6-1.0 ft), yellowish-brown (10YR5/6) silt loam; weak, medium, platy structure; slightly sticky, slightly plastic wet consistence; firm moist consistence; few, medium roots; $\mathrm{pH}=4.5$; level, clear boundary.

2Bw 31-41 cm (1.0-1.3 ft), yellowish-brown (10YR5/4-10YR5/6) silt loam; weak, structureless to medium, subangular blocky; slightly sticky, slightly plastic wet consistence; friable to firm moist consistence; few, medium roots; $\mathrm{pH}=4.7$; level, gradual boundary.

2Bt1 41-54 cm (1.3-1.8 ft), yellowish-brown (10YR5/4-10YR5/6) silt loam; common, fine, faint, reticulate, light yellowish-brown (10YR6/4), common, fine, faint, reticulate, yellowish-brown (10YR5/8), and few, fine, distinct, rounded, black (10YR2/1) mottles; weak, medium, subangular blocky structure; slightly sticky, slightly plastic wet consistence; friable to firm moist consistence; few, medium roots; $\mathrm{pH}=4.9$; level, gradual boundary.

2Bt2 54-68 cm (1.3-2.2 ft), 50\% strong-brown (7.5YR5/6), 508 light brownish-gray (10YR6/2) silt loam (gray areas surrounding brown, distinct boundaries); common, distinct, medium, reticulate to sub-rounded (concretionary), strong-brown (7.5YR5/8) mottles, and few, distinct, fine, rounded, black (7.5YR2/0) concretions; moderate, medium, angular-blocky structure; sticky, plastic wet consistence; firm to very firm moist consistence; few, thin, patchy clay films on ped faces and channels; few, fine roots; $\mathrm{pH}=4.7$; level, gradual boundary.

$2 \mathrm{Btx} 168-80 \mathrm{~cm}(2.2-2.6 \mathrm{ft}), 30 \%$ light-gray $(2.5 \mathrm{Y} 7 / 2)$ distinct in tongues, 708 strong-brown $(7.5 \mathrm{YR} 5 / 6)$ in ped interiors, silt loam; common, distinct, fine to medium, reticulate to sub-rounded, strong-brown (7.5YR5/8) mottles and few, distinct, fine, black (7.5YR2/0) concretions; moderate, medium, angular-blocky structure transitional to weak, medium prismatic; slightly sticky, slightly plastic wet consistence; firm to very firm moist consistence; few, thin, patchy, light-gray $(2.5 \mathrm{Y} 7 / 1)$ clay films on ped faces (appear to be in process of destruction); few, fine roots; $\mathrm{pH}=4.4$; clear, wavy boundary. 
313

2 Btx2 $80-90 \mathrm{~cm}(2.6-3.0 \mathrm{ft}), 30 \%$ light-gray $(2.5 \mathrm{Y7} / 2)$ distinct in tongues, 708 strong-brown $(7.5$ YR $5 / 6)$ in ped interiors, silty clay loam; common, distinct, fine to medium, reticulate to sub-rounded, strong-brown (7.5YR5/8) and common, distinct to faint, fine, light brownish-gray (10YR6/2) mottles, and few, distinct, fine, rounded, black (7.5YR2/0) concretions; moderate, medium, prismatic structure; sticky, plastic wet consistence; firm to very firm moist consistence; few, moderately thick, patchy, light-gray (2.5Y7/1) clay films on ped faces (appear to be in process of destruction); few, fine roots; $\mathrm{pH}=4.3$; abrupt, irregular boundary tonguing into underlying horizons.

314

2Btx3 90-103 cm (3.0-3.4 ft), 20\% 1ight-gray (2.5Y7/2) distinct in tongues, 808 strong-brown (7.5YR5/6-7.5YR5/8) in ped interiors, silty clay loam; common, distinct, fine to medium, reticulate to sub-rounded, strong-brown ( 7.5 YR $5 / 8)$ and common, distinct to faint, fine, light brownish-gray (10YR6/2) mottles, and few, distinct, fine, rounded, black ( 7.5 YR2/0) concretions; moderate, medium, prismatic structure breaking to moderate, medium, angular; sticky, plastic wet consistence; very firm moist consistence; few, thick, continuous, gray (10YR6/2) clay films on ped faces in tongues; few, fine roots; $\mathrm{pH}=4.1$; abrupt tongues from overlying horizons cut gradual, leve1 boundary.

315

2Btx4 103-113 cm (3.4-3.7 ft), 208 1ight-gray (2.5Y7/2) distinct in tongues, 808 strong-brown (7.5YR5/6-7.5YR5/8) in ped interiors, silty clay loam; common, distinct, fine to medium, reticulate to sub-rounded, strong-brown ( 7.5 YR $5 / 8)$ and common, distinct to faint, fine, light brownish-gray (10YR6/2) mottles, and few, distinct, fine, rounded, black (7.5YR2/0) concretions; strong, medium, prismatic structure; sticky, plastic wet consistence; very firm moist consistence; few, thick, continuous, gray (10YR6/2) clay films on ped faces in tongues; few fine roots; $\mathrm{pH}=4.0$; abrupt tongues from overlying horizons cut gradual, level boundary.

316

2Btx5 $113-130 \mathrm{~cm}(3.7-4.3 \mathrm{ft}), 108$ 1ight-gray $(2.5 \mathrm{Y} 7 / 2)$ distinct in tongues, 908 strong-brown (7.5YR5/6-7.5YR5/8) in ped interiors, silty clay loam; few, distinct, fine to medium, reticulate to sub-rounded, strong-brown ( 7.5 YR5/8) and few, distinct to faint, fine, 1ight brownish-gray (10YR6/2) mottles, and few, distinct, fine, rounded, black (7.5YR2/0) concretions; strong, coarse, prismatic structure breaking to weak, medium, angular-blocky; sticky, plastic wet consistence; very firm moist consistence; few, thick, continuous, gray (10YR6/2) clay films on ped faces in tongues; $1,10-\mathrm{cm}$ diameter cobble at $113 \mathrm{~cm}$; few fine roots; $\mathrm{pH}=3.9$; abrupt tongues from overlying horizons cut gradual, level boundary.

317

2Btx6 $130-150 \mathrm{~cm}(4.3-4.9 \mathrm{ft}), 108$ light-gray $(2.5 \mathrm{Y} / 2)$ distinct in 
tongues, 908 strong-brown (7.5YR5/6-7.5YR4/6) in ped interiors, silty clay loam; common, distinct, fine to medium, reticulate to sub-rounded, strong-brown (7.5YR5/8) mottles on ped faces; few, distinct to faint, fine, light brownish-gray (10YR6/2) mottles in ped interiors; strong, medium, prismatic structure breaking to weak, medium, angular-blocky; sticky, plastic wet consistence; very firm moist consistence; few, thick, continuous, gray $(10$ YR6/2) clay films on ped faces in tongues; few fine roots; $\mathrm{pH}=4.2$; abrupt tongues from overlying horizons cut gradual, level boundary.

318

2Btx7 150-165 cm (4.9-5.4 ft), 108 light-gray $(2.5 Y 7 / 2)$ distinct in tongues, 458 strong-brown (7.5YR5/8), 458 light yellowish-brown (10YR6/4), distinct, in ped interiors, silty clay loam; strong, coarse, prismatic structure; sticky, plastic wet consistence; very firm moist consistence; few, thick, continuous, gray (10YR6/2) clay films on ped faces in tongues; no roots; several 10- to $20-\mathrm{cm}$-diameter cobbles; $\mathrm{pH}=4.4$; abrupt tongues from overlying horizons cut gradual, level boundary.

319

2Btx8 165-180 cm (5.4-5.9 ft), 58 light yellowish-brown (10YR6/4) faint tongues, $95 \%$ reddish-brown (5YR5/4) clay loam; few, fine, distinct, reticulate yellowish-red to strong-brown (5YR5/8-7.5YR5/8) mottles; moderate, coarse, prismatic structure; sticky, plastic wet consistence; very firm moist consistence; few, thin, patchy, gray (10YR6/2) clay films on ped faces in tongues; no roots; scattered, matrix-supported pebbles and cobbles; $\mathrm{pH}=4.7$; tongues are very faint; gradual, level abrupt tongues from overlying horizons cut gradual, level boundary.

320

3BCl 180-200 cm (5.9-6.6 ft), reddish-brown (5YR5/4) loam to clay loam; few, fine, distinct, reticulate (5YR5/8-7.5YR5/8) mottles; very weak, coarse, prismatic structure; slightly sticky, slightly plastic wet consistence; firm moist consistence; common, sub-rounded to we11-rounded, siltstone and sandstone pebbles and cobbles up to $10 \mathrm{~cm}$ mean diameter; $\mathrm{pH}=5.7$; level, gradual boundary.

321

3BC2 200-250 cm (6.6-8.2 ft), reddish-brown (5YR5/4) loam; few, fine, distinct, reticulate, reddish-yellow to strong-brown

(5YR5/8-7.5YR5/8) mottles; very weak, coarse prismatic structure to structureless; slightly sticky, slightly plastic wet consistence; friable moist consistence; common, sub-rounded to well-rounded, siltstone and sandstone pebbles and cobbles up to $10 \mathrm{~cm}$ mean diameter; $\mathrm{pH}=5.9$; level, gradual boundary.

322

3C1 250-300 cm (8.2-9.8 ft), reddish-brown (5YR5/4) loam; subtle, 1-3 $\mathrm{cm}$ thick beds, alternating very fine sand and silt; few, fine, distinct, reticulate, reddish-yellow to strong-brown

(5YR5/8-7.5YR5/8) mottles; structureless; slightly sticky, slightly plastic wet consistence; friable moist consistence; common, sub-rounded to well-rounded, siltstone and sandstone pebbles and 
cobbles up to $10 \mathrm{~cm}$ mean diameter, matrix-supported; $\mathrm{pH}=5.3$; leve1, gradual boundary.

323

$3 \mathrm{C} 2$

324

3C3 380-400 cm (11.5-13.1 ft), reddish-brown (5YR5/4) loamy, clast-supported grave1; structureless, bedded; $\mathrm{pH}=4.7$.

Test pit \#4

Fill 0-43 cm (0-1.4 ft) (not sampled), very dark gray (5YR3/1), granuleto pebble-size coal fragments in silty ash matrix with few, pebble-size, red $(2.5$ YR5/1) to white (10YR8/1) carbonate-rich, slag fragments; very abrupt, very wavy boundary.

325

A1 43-46 cm (1.4-1.5 ft), yellowish-brown (10YR5/4-5/6) loamy sand; very weak, medium, granular structure to structureless; non sticky, non plastic wet consistence; loose moist consistence; many fine and medium roots; $\mathrm{pH}=4.1$; very abrupt, level boundary.

326

$2 \mathrm{~A} 2$

327

3Ap 51-61 cm (1.7-2.0 ft), dark-brown (10YR4/3) loam to silt loam; weak, medium, subangular-blocky structure breaking to weak, medium, granular; slightly sticky, non plastic wet consistence; friable moist consistence; many medium and coarse roots; $\mathrm{pH}=4.1$; abrupt, leve1 boundary.

3BE 61-77 cm (2.0-2.5 ft), yellowish-brown (10YR5/4) loam; common, fine, faint, strong-brown (7.5YR5/6) mottles; moderate, fine, subangular-blocky structure; slightly sticky, non plastic wet consistence; friable moist consistence; few coarse roots; $\mathrm{pH}=4.0$; gradual, level boundary.

3Btl 77-87 cm (2.5-2.8 ft), yellowish-brown (10YR5/4) loam; many, fine, 
faint, strong-brown (7.5YR5/6) mottles; moderate, medium, subangular-blocky structure; slightly sticky, non plastic wet consistence; friable moist consistence; few, thin, patchy clay films of ped faces; few coarse roots; $\mathrm{pH}=4.3$; gradual, level boundary.

330

3Bt2 87-109 cm (2.8-3.6 ft), 508 strong-brown (7.5YR5/6), 508 light brownish-gray (10YR6/2) silt loam (gray areas surrounding brown, distinct boundaries); few, distinct, fine, rounded, black (7.5YR2/0) concretions; weak, medium, prismatic structure breaking to moderate, medium, angular-blocky; slightly sticky, plastic wet consistence; firm moist consistence; few, thin, patchy clay films on ped faces and channels (in process of being stripped); few, medium roots; $\mathrm{pH}=4.4$; level, gradual boundary.

331

3Btxl 109-123 cm (3.6-4.0 ft), distinctly mottled: $33 \%$ light grayish-brown (10YR6/2), 338 strong-brown ( 7.5 YR5/6), 338 reddish-brown (5YR5/4) (gray surrounding strong-brown and reddish-brown concentrically), silt loam; common, faint to distinct, fine to medium, rounded, black ( $7.5 Y R 2 / 0)$ concretions; moderate, medium, prismatic structure breaking to moderate, medium, angular-blocky; slightly sticky, plastic wet consistence; firm moist consistence; few, thin, patchy, reddish-brown (5YR5/4) clay films on ped faces and channels (in process of being stripped); few, fine roots; $\mathrm{pH}=4.6$; faint to distinct tongues coalescing to break through lower horizons; level, gradual boundary.

332

3Btx2 123-142 cm (4.0-4.6 ft), 50\% distinct light grayish-brown (10YR6/2) concentric around $25 \%$ strong-brown (7.5YR5/6) and $25 \%$ reddish-brown to black (5YR5/4 to 7.5YR2/0), silt loam; moderate medium, prismatic structure; slightly sticky, plastic wet consistence; firm to very firm moist consistence; few, thin, patchy, reddish-brown (5YR5/4) clay films on ped faces and channels (in process of being stripped); few, fine roots; $\mathrm{pH}=4.3$; distinct tongues; level, gradual boundary.

333

3Btx3 142-162 cm (4.6-5.3 ft), 508 distinct light grayish-brown (10YR6/2) concentric around $25 \%$ strong-brown (7.5YR5/6) and $25 \%$ reddish-brown to black (5YR5/4 to 7.5YR2/0), silt loam; moderate medium, prismatic structure breaking to moderate, medium, angular-blocky; slightly sticky, plastic wet consistence; very firm moist consistence; no clay films; common, angular to well-rounded, 5- to $15-\mathrm{cm}$ mean diameter pebbles and cobbles; few, fine roots; $\mathrm{pH}=4.3$; distinct tongues; level, gradual boundary.

334

3Bxt4 162-182 cm (5.3-6,0 ft), 508 distinct light grayish-brown (10YR6/2) concentric around distinct $25 \%$ strong-brown (7.5YR4/6) and $25 \%$ reddish-brown to black (5YR5/4 to 7.5 YR2/0), cobbly silt loam; moderate medium, prismatic structure breaking to moderate, medium, 
angular-blocky; slightly sticky, plastic wet consistence; very firm moist consistence; no clay films; common, angular to well-rounded, 10 - to $20-\mathrm{cm}$ mean diameter pebbles and cobbles; few, fine roots; $\mathrm{pH}=4.6$; distinct tongues; level, gradual boundary.

335

3Bxt5 182-200 cm (6.0-6.6 ft), 508 distinct light grayish-brown (10YR6/2) concentric around distinct 258 strong-brown $(7.5 Y R 4 / 6)$ and 258 reddish-brown to black (5YR5/4 to 7.5 YR2/0), cobbly loam to silt loam; moderate medium, prismatic structure breaking to moderate, medium, angular blocky; slightly sticky, plastic wet consistence; very firm moist consistence; no clay films; common, angular to well-rounded, $10-20 \mathrm{~cm}$ mean diameter pebbles and cobbles; few, fine roots; $\mathrm{pH}=4.6$; distinct tongues; level, gradual boundary.

338

4BC1 200-230 cm (6.6-7.5 ft), 508 brown (7.5YR5/4) and 508 strong-brown (7.5YR4/6), cobbly loam; weak medium to coarse, prismatic structure; slightly sticky, slightly plastic wet consistence; very firm moist consistence; no clay films; common, angular to well-rounded, $10-20 \mathrm{~cm}$ mean diameter pebbles and cobbles; $\mathrm{pH}=4.6$; distinct tongues; level, gradual boundary.

337

4BC2 230-265 cm (7.5-8.7 ft), brown (7.5YR5/4) cobbly loam with common, faint, medium, strong-brown (7.5YT5/6-5/8) mottles; weak, coarse prismatic structure; slightly sticky, slightly plastic wet consistence; firm moist consistence; few, scattered, angular to well-rounded cobbles; $\mathrm{pH}=4.4$; tongues faint; level, gradual boundary.

4BC3 265-290 cm (8.7-9.5 ft), brown (7.5YR5/4) cobbly loam with common, faint, medium strong-brown (7.5YT5/6-5/8) mottles; very weak, coarse prismatic structure; slightly sticky, slightly plastic wet consistence; firm moist consistence; few, scattered, angular to well-rounded cobbles; $\mathrm{pH}=4.6$; tongues faint.

Test Pit \#6

339

A $\quad 0-5 \mathrm{~cm}(0-.2 \mathrm{ft})$, very dark grayish-brown (10YR3/2) fine sandy loam; moderate, medium granular structure; slightly sticky, slightly plastic wet consistence; loose moist consistence; many fine roots; $\mathrm{pH}=5.0$; wavy, abrupt boundary.

$\mathrm{AB} \quad 5-19 \mathrm{~cm}(.2-.6 \mathrm{ft})$, dark-brown (7.5YR3/4) fine sandy loam; weak, medium, subangular-blocky structure; slightly sticky, slightly plastic wet consistence; friable moist consistence; many fine roots; $\mathrm{pH}=5.7$; level, gradual boundary.

Bt1 19-33 cm (.6-1.1 ft), brown to dark-brown (7.5YR4/4) fine sandy loam; moderate, medium, subangular-blocky structure; slightly 
sticky, slightly plastic wet consistence; friable moist consistence; many fine roots; $\mathrm{pH}=5.8$; level, gradual boundary.

342

Bt2

343

Bt3

344

Bt4 64-78 cm (2.1-2.6 ft), brown to strong-brown (7.5YR5/4-5/6) 1oam to silt loam; moderate to strong, medium, subangular blocky structure; slightly sticky, slightly plastic wet consistence; firm moist consistence; common, thin, clay films on ped faces; few fine roots; few scattered, matrix-supported cobbles and pebbles less than $10 \mathrm{~cm}$ mean diameter, $\mathrm{pH}=6.5$; level, gradual boundary.

345

Btx1 78-92 cm (2.6-3.0 ft), strong-brown (7.5YR5/6) silt loam with common, distinct, fine, reticulate gray $(7.5$ YR $6 / 2)$ mottles on ped faces, concentrically zoned and grading inward to strong-brown (7.5YR5/8) and black (7.5YR2/0); weak, coarse prismatic structure breaking to medium, angular-blocky; slightly sticky, slightly plastic wet consistence; firm moist consistence; common, thin, clay films on ped faces; few fine roots; few scattered, matrix-supported cobbles and pebbles less than $10 \mathrm{~cm}$ mean diameter, $\mathrm{pH}=6.6$; level, gradual boundary.

346

Btx2 92-115 cm (3.0-3.8 ft), strong-brown (7.5YR5/6) silt loam with common, distinct, fine, reticulate gray (7.5YR6/2) mottles on prismatic ped faces, concentrically zoned and grading inward to strong-brown (7.5YR5/8) and black (7.5YR2/0); weak, coarse prismatic structure; slightly sticky, slightly plastic wet consistence; firm moist consistence; few, thin, clay films on ped faces; few fine roots; few scattered, matrix-supported cobbles and pebbles less than $10 \mathrm{~cm}$ mean diameter, $\mathrm{pH}=6.6$; level, gradual boundary.

347

Btx3 115-130 cm (3.8-4.3 ft), strong-brown (7.5YR5/6) silt loam with common, distinct, fine, reticulate gray $(7.5 \mathrm{YR} 6 / 2)$ mottles on prismatic ped faces, concentrically zoned and grading inward to strong-brown (7.5YR5/8) and black (7.5YR2/0); weak, coarse prismatic structure; slightly sticky, slightly plastic wet consistence; firm moist consistence; few, thin, clay films on ped 
faces; few scattered, matrix-supported cobbles and pebbles less than $10-\mathrm{cm}$ mean diameter, $\mathrm{pH}=6.6$; leve1, gradual boundary.

348

Btx3 130-150 cm (4.3-4.9 ft), strong-brown (7.5YR5/6) silt loam with few, faint, fine, reticulate gray (7.5YR6/2) mottles on prismatic ped faces, concentrically zoned and grading inward to strong-brown (7.5YR5/8) and black (7.5YR2/0); weak, coarse prismatic structure; slightly sticky, slightly plastic wet consistence; firm moist consistence; few, thin, clay films on ped faces; few scattered, matrix-supported cobbles and pebbles less than $10-\mathrm{cm}$ mean diameter, $\mathrm{pH}=6.4$; leve1, gradual boundary.

349

BC1 150-170 cm (4.9-5.6 ft), strong-brown (7.5YR5/6) silt loam; massive to weak, coarse prismatic structure; slightly sticky, slightly plastic wet consistence; firm moist consistence; few scattered, matrix-supported cobbles and pebbles less than $10-\mathrm{cm}$ mean diameter, $\mathrm{pH}=5.6$; leve1, gradual boundary.

BC2 170-200 cm (5.6-6.6 ft), strong-brown (7.5YR5/6) silt loam; massive structure; slightly sticky, slightly plastic wet consistence;

friable to firm moist consistence; few scattered, matrix-supported cobbles and pebbles less than $10 \mathrm{~cm}$ mean diameter, $\mathrm{pH}=5.4$.

Test Pit \#10

Fil1 0-5 cm (0-0.2 ft) (not sampled), very dark gray (5YR3/1), granuleto pebble-size coal fragments in silty matrix; very abrupt, wavy boundary.

351

Ap 5-15 cm (0.2-0.5 ft) dark-brown (10YR4/3) silt loam; weak, medium, platy structure breaking to weak, medium, granular; slightly sticky, slightly plastic wet consistence; friable moist consistence; common fine to coarse roots; $\mathrm{pH}=4.3$; clear, wavy boundary.

352

$\mathrm{AB}$ 15-25 cm (0.5-0.8 ft), dark ye11owish-brown (10YR4/4) silt 1oam; weak, medium, subangular-blocky structure breaking to weak, fine granular; slightly sticky, slightly plastic wet consistence; friable moist consistence; common fine to coarse roots; $\mathrm{pH}=4.4$; gradual, wavy boundary.

353

Bt1 25-35 cm (0.8-1.1 ft), brown to strong-brown (7.5YR5/4-5/6) silt 1oam to silty clay loam; weak, medium, subangular blocky structure breaking to strong, angular-blocky; sticky, plastic wet consistence; friable to firm moist consistence; few, very thin, patchy dark yellowish-brown (10YR4/4) clay films on ped faces; few fine roots; $\mathrm{pH}=4.6$; gradual, level boundary. 

silt loam to silty clay loam; moderate, medium, subangular-blocky structure breaking to moderate, angular-blocky; sticky, plastic wet consistence; firm moist consistence; few, thin, clay films on ped faces and in channels; few fine roots; $\mathrm{pH}=4.6$; gradual, leve1 boundary.

355

Bt3

356

Bt4

357

Bt5

358

Bt6

359

Bt7

49-65 cm (1.6-2.1 ft), strong-brown (7.5YR5/6) silt loam with few, faint, fine reticulate brownish-ye11ow (10YR6/3) and few, faint, fine black ( 7.5 YR2/0) mottles on ped faces; moderate, fine to medium, angular-blocky structure; slight1y sticky, slightly plastic wet consistence; firm moist consistence; common, moderately thick, clay films on ped faces and in channels; few medium roots; $\mathrm{pH}=4.6$; gradua1, level boundary.

65-80 cm (2.1-2.6 ft), strong-brown (7.5YR5/6) silt loam with few, faint, fine reticulate brownish-yellow (10YR6/3) and few, faint, fine black (7.5YR2/0) mottles on ped faces; moderate, medium, angular-blocky structure; slight1y sticky, slightly plastic wet consistence; firm moist consistence; common, moderately thick, dark-brown (7.5YR4/4) clay films on ped faces and in channels; few fine roots; $\mathrm{pH}=4.0$; gradual, level boundary.

$80-95 \mathrm{~cm}(2.6-3.1 \mathrm{ft})$, strong-brown (7.5YR5/6) silt loam with common, fine, faint to distinct, black (7.5YR2/0) mottles on ped faces; moderate, medium, angular-blocky structure; slightly sticky, slightly plastic wet consistence; firm moist consistence; common, moderately thick, dark-brown (7.5YR4/4) clay films on ped faces and in channels; few, scattered 4-6 cm mean diameter, matrix-supported pebbles at $86-90 \mathrm{~cm}$; few fine roots; $\mathrm{pH}=4.1$; gradual, level boundary.

95-110 cm (3.1-3.6 ft), strong-brown (7.5YR5/6) silt loam with common, fine, faint to distinct, black (7.5YR2/0) mottles on ped faces and faint to distinct, light brownish gray (10YR6/2) vertica1 tongues along ped boundaries; weak, coarse, prismatic structure breaking to weak, medium, angular-blocky; slightly sticky, slightly plastic wet consistence; firm moist consistence; common, moderately thick, dark-brown (7.5YR4/4) clay films on ped faces; $\mathrm{pH}=4.2$; gradua1, leve1 boundary.

$110-125 \mathrm{~cm}(3.6-4.1 \mathrm{ft})$, strong-brown (7.5YR5/6) silt 1oam with few, fine, faint to distinct, black ( 7.5 YR2/0) mottles on ped faces and faint, light brownish-gray (10YR6/2) vertical tongues along ped boundaries; weak, coarse, prismatic structure breaking to weak, medium, angular blocky; slightly sticky, slightly plastic wet consistence; firm moist consistence; few, moderately thick, dark-brown (7.5YR4/4) clay films on ped faces; few, scattered, angular to rounded, 2 - to $10-\mathrm{cm}$ mean diameter, matrix-supported pebbles and cobbles; $\mathrm{pH}=4.1$; gradual, leve1 boundary. 
Btx1 125-140 cm (4.1-4.6 ft), strong-brown (7.5YR5/6) silt loam with faint, light brownish-gray (10YR6/2) vertical tongues along ped boundaries; weak, coarse, prismatic structure breaking to weak, medium, angular-blocky; slightly sticky, slightly plastic wet consistence; firm moist consistence; few, thin, dark-brown (7.5YR4/4) clay films on ped faces; few, scattered, angular to rounded, 2 - to $10-\mathrm{cm}$ mean diameter, matrix-supported pebbles and cobbles; $\mathrm{pH}=4.5$; gradual, level boundary.

361

Btx2 140-160 cm (4.6-5.2 ft), strong-brown (7.5YR5/6) loam to silt loam with subtle interfingerings of fine sandy loam layers and faint, light brownish-gray (10YR6/2) vertical tongues along ped boundaries; weak, coarse, prismatic structure; slightly sticky, slightly plastic wet consistence; firm moist consistence; $\mathrm{pH}=4.5$; gradual, level boundary.

362

Btx3 160-180 cm (5.2-5.9 ft), strong-brown (7.5YR5/6) loam to silt loam with subtle interfingerings of fine sandy loam layers and faint, light brownish-gray (10YR6/2) vertical tongues along ped boundaries; weak, coarse, prismatic structure; slightly sticky, slightly plastic wet consistence; very firm moist consistence; few, scattered, angular to rounded, 2 - to $10-\mathrm{cm}$ mean diameter, matrix-supported pebbles and cobbles in layer $170-180 \mathrm{~cm} ; \mathrm{pH}=4.5$; gradual, level boundary.

363

Btx4 180-200 cm (5.9-6.6 ft), strong-brown (7.5YR5/6) loam to silt loam with subtle interfingerings of fine sandy loam layers and distinct, light brownish-gray (10YR6/2) vertical tongues with distinct, fine, reticulate strong-brown ( 7.5 YR5/8) to black (7.5YR2/0) mottles on margins along ped boundaries; weak, coarse, prismatic structure; slightly sticky, slightly plastic wet consistence; very firm moist consistence; $\mathrm{pH}=4.6$; gradual, level boundary.

364

BC1 200-250 cm (6.6-8.2 ft), yellowish-red (5YR4/4) loam with subtle, 2 - to $4-\mathrm{cm}$-thick fine sand laminae; common, distinct, gray

(7.5YR7/2) tongues along ped boundaries with strong brown

(7.5YR5/8) margins; massive to weak, coarse, prismatic structure; slightly sticky, slightly plastic wet consistence; very firm moist consistence; common, scattered, angular to sub-rounded, matrix-supported pebbles and cobbles up to $10-\mathrm{cm}$ mean diameter; $\mathrm{pH}=4.9$; gradual, leve1 boundary.

BC2 250-290 cm (8.2-9.5 ft), yellowish-red (5YR4/4) loam with subtle, 2 - to $4-\mathrm{cm}$-thick fine sand laminae; common, distinct, gray

(7.5YR7/2) tongues along ped boundaries with strong brown (7.5YR5/8) margins; massive to weak, coarse, prismatic structure; slightly sticky, slightly plastic wet consistence; very firm moist consistence; common, scattered, angular to sub-rounded, 
matrix-supported pebbles and cobbles up to $10-\mathrm{cm}$ mean diameter;

$\mathrm{pH}=5.3$; gradual, level boundary.

366

BC3 290-320 cm (9.5-10.5 ft), yellowish-red (5YR4/4) loam with subtle,

2 - to 4-cm-thick fine sand laminae; common, distinct, gray

(7.5YR $7 / 2$ ) tongues along ped boundaries with strong brown

(7.5YR5/8) margins; massive to weak, coarse, prismatic structure;

slightly sticky, slightly plastic wet consistence; very firm moist

consistence; common, scattered, angular to sub-rounded,

matrix-supported pebbles and cobbles up to $10-\mathrm{cm}$ mean diameter;

$\mathrm{pH}=5.6$; gradual, level boundary.

Test Pit \#19

367

Ap $0-15 \mathrm{~cm}(0-0.5 \mathrm{ft})$ dark-brown (10YR3/2) silt loam; weak, fine, granular structure; slightly sticky, slightly plastic wet consistence; loose moist consistence; many fine to coarse roots; $\mathrm{pH}=4.3$; abrupt, level boundary.

$15-27 \mathrm{~cm}$ (0.5-0.9 ft), strong-brown (7.5YR4/6) silt loam; weak, medium, subangular to angular-blocky structure; slightly sticky, slightly plastic wet consistence; friable moist consistence; common fine to coarse roots; $\mathrm{pH}=4.2$; gradual, leve1 boundary.

Bt1 27-41 cm (0.9-1.3 ft), strong-brown (7.5YR4/6) silt loam; weak to moderate, medium, subangular-blocky structure; slightly sticky, plastic wet consistence; friable to firm moist consistence; few, very thin, patchy dark yellowish brown (10YR4/4) clay films on ped faces; few fine roots; few, scattered granules and pebbles; $\mathrm{pH}=4.5$; gradual, level boundary.

Bt2 41-56 cm (1.3-1.8 ft), strong-brown (7.5YR4/6) silt loam; moderate, medium, subangular to angular-blocky structure; slightly sticky, plastic wet consistence; firm moist consistence; few, thin, patchy, strong-brown ( 7.5 YR5/6) clay films on ped faces and in channels; few fine roots; $\mathrm{pH}=4.6$; gradual, level boundary.

Bt3 56-70 cm (1.8-2.3 ft), strong-brown (7.5YR5/4-5/6) silt loam with few, faint, fine reticulate brownish-yellow (10YR6/3) and few, faint, fine black ( 7.5 YR2/0) mottles on ped faces; moderate, medium, angular-blocky structure; slightly sticky, plastic wet consistence; firm moist consistence; few, thin, patchy, strong-brown (7.5YR5/6-5/8) clay films on ped faces and in channels; few medium roots; $\mathrm{pH}=4.6$; gradual, level boundary. 
coarse prismatic structure breaking to moderate, medium, angular-blocky; slightly sticky, slightly plastic wet consistence; firm moist consistence; few, thin, patchy, dark-brown (7.5YR4/4) clay films on ped faces and in channels; few medium roots; $\mathrm{pH}=4.5$; gradual, level boundary.

373

Btx2 89-109 cm (2.9-3.6 ft), 508 light brownish-gray (10YR6/2) and $50 \%$ strong-brown (7.5YR5/6) diffusely to distinctly intermottled, silt loam (light brownish-gray parts form weak tongues along prismatic peds); weak, coarse prismatic structure; common, fine, faint to distinct, black (7.5YR2/0) mottles with concentric rings of strong-brown (7.5YR5/8); slightly sticky, slightly plastic wet consistence; firm to very firm moist consistence; few, thin, patchy, brown (7.5YR4/4) clay films on ped faces and in channels; few fine roots; $\mathrm{pH}=4.5$; gradual, level boundary.

374

Btx3 109-129 cm (3.6-4.2 ft), 308 light brownish-gray (10YR6/2)

distinctly tonguing into 808 strong-brown (7.5YR4/4) loam to silt loam; moderate, coarse prismatic structure; common, fine, faint to distinct, black (7.5YR2/0) mottles with concentric rings of strong-brown (7.5YR5/8); slightly sticky, slightly plastic wet consistence; very firm moist consistence; few, thin, patchy, brown (7.5YR4/4) clay films on ped faces and in channels; one well sorted, $8-\mathrm{cm}$-thick layer of clast-supported, rounded to sub-angular pebbles; $\mathrm{pH}=4.5$; gradual, level boundary.

375

Btx4 129-149 cm (4.2-4.9 ft), 308 light brownish-gray (10YR6/2) distinctly tonguing into 808 strong-brown (7.5YR4/4) loam; moderate, coarse prismatic structure; common, fine, faint to distinct, black (7.5YR2/0) mottles with concentric rings of strong-brown (7.5YR5/8); slightly sticky, slightly plastic wet consistence; very firm moist consistence; few, thin, patchy, brown (7.5YR4/4) clay films on ped faces and in channels; few, scattered, angular to rounded, 2 - to $10-\mathrm{cm}$ mean diameter, matrix-supported pebbles and cobbles; $\mathrm{pH}=4.4$; gradual, level boundary.

376

Bx1 149-169 cm (4.9-5.5 ft), 308 light brownish-gray (10YR6/2) distinctly tonguing into $80 \%$ strong-brown ( $7.5 Y$ Y $4 / 4$ ) loam; moderate, coarse prismatic structure; common, fine, faint to distinct, black (7.5YR2/0) mottles with concentric rings of strong-brown (7.5YR5/8); slightly sticky, slightly plastic wet consistence; firm moist consistence; few, scattered, angular to rounded, matrix-supported pebbles; $\mathrm{pH}=4.3$; gradual, level boundary.

377

Bx2 169-190 cm (5.5-6.2 ft), strong-brown (7.5YR5/6) loam to silt loam with subtle interfingerings of fine sandy loam layers and faint, light brownish-gray (10YR6/2) vertical tongues along ped boundaries; weak, coarse, prismatic structure; slightly sticky, slightly plastic wet consistence; firm moist consistence; $\mathrm{pH}=4.4$; gradual, level boundary. 
BC1 190-220 cm (6.2-7.2 ft), strong-brown (7.5YR5/6) loam to silt loam with subtle interfingerings of fine sandy loam layers and faint, light brownish-gray (10YR6/2) vertical tongues along ped boundaries; weak, coarse, prismatic structure; slightly sticky, slightly plastic wet consistence; firm moist consistence; few, scattered, angular to rounded, 0.5 - to $5-\mathrm{cm}$ mean diameter, matrix-supported pebbles; $\mathrm{pH}=4.7$; gradual, level boundary.

BC2 220-255 cm (7.2-8.4 ft), strong-brown (7.5YR5/6) silt loam with subtle interfingerings of fine sandy loam layers and distinct to faint, light brownish-gray (10YR6/2) vertical tongues with faint, fine, reticulate strong-brown ( 7.5 YR5/8) margins; massive to weak, coarse, prismatic structure; slightly sticky, slightly plastic wet consistence; firm moist consistence; $\mathrm{pH}=4.8$; gradual, level boundary. with subtle interfingerings of fine sandy loam layers; massive structure; slightly sticky, slightly plastic wet consistence; firm moist consistence; $\mathrm{pH}=4.6$; gradual, level boundary. 


\section{Laboratory data}

Particle size analytical results are given in table 1 and shown graphically for each profile in figure 5. The left hand graph of each set of three graphs in figure 5 shows the distribution of sand-size particles based on the five sand fractions recalculated to equal 1008 . This type of diagram is useful in discriminating layering or parent-material particle-size gradations within the soil profiles based on the assumption that sand-size particles are least susceptible to weathering. Layering and gradation within profiles should be avoided when using soils for interpolative dating since these trends tend to mask particle-size distributions and geochemical changes produced by weathering alone. It is important to note in this case that all of these soil profiles have pedogenic concretions formed in parts of the $B$ horizons. This effect can be seen in high coarse and very coarse sand percentages from 110 to $140 \mathrm{~cm}$ in $T P 10$, and 90 to $170 \mathrm{~cm}$ in $T P 19$. TP 1 shows distinctly coarser sands at the base, indicating a fining-upward sequence. Coarser basal sands are also notable in TP 6 and to a lesser extent in TP 10.

The middle graph for each soil profile shows the distribution of clay particle size material with depth. Emphasis is placed on clay because the production of clay-size material is one of the more orderly pedogenic processes. Pedogenic clay usually accumulates in the B horizons of soils due to particulate transport from overlying horizons and in situ formation; older, more-weathered soils will have distinct bulges in the B-horizon portion of the clay depth distribution. Such bulges are apparent in all profiles except TP 19, the top of which was probably eroded at some time, as indicated by the abrupt contact at the base of the Ap horizon and this horizon's anomalous coarse sand content (fig. 5).

The bulge in TP 1 is enhanced by the primary, fining-upward particle size distribution. Because TP 6 was not sampled to the base of the $B$ horizon accumulation, resolution of the base of the bulge is not apparent.

The right-hand graph for each profile is a ternary particle-size graph showing the textural category of the samples.

Particle size data were used as criteria for choosing a profile for more detailed laboratory analyses. TP 1 was not considered because of its primary fining-upward size distribution. TP 6 and TP 19 were not used because the bottom and top, respectively, of the profiles were not sampled. TP 10 was chosen in favor of TP 4 because TP 10 has less primary particle-size variation and was sampled over a deeper interval. 


\begin{tabular}{|c|c|c|c|c|c|c|c|c|c|}
\hline Serial & $\underline{\mathrm{VCS}}$ & $\underline{\mathrm{CS}}$ & $\underline{\mathrm{MS}}$ & $\underline{F S}$ & $\underline{\mathrm{VFS}}$ & $\underline{\operatorname{CSI}}$ & $\underline{F S I}$ & $\underline{\text { CLAY }}$ & $\underline{\mathrm{BD}}$ \\
\hline 308.00 & 0.11 & 0.83 & 1.02 & 1.75 & 5.26 & 25.98 & 40.21 & 24.85 & 1.88 \\
\hline 309.00 & 0.77 & 0.69 & 0.92 & 1.77 & 5.16 & 24.11 & 40.55 & 26.03 & 1.73 \\
\hline 310.00 & 1.08 & 0.53 & 0.75 & 1.92 & 5.12 & 27.00 & 36.96 & 26.65 & 1.65 \\
\hline 311.00 & 0.92 & 0.93 & 0.93 & 1.77 & 5.23 & 23.81 & 40.59 & 25.82 & 1.62 \\
\hline 312.00 & 0.61 & 0.92 & 0.92 & 1.61 & 4.23 & 26.26 & 38.76 & 26.69 & 1.68 \\
\hline 313.00 & 0.42 & 0.37 & 0.53 & 1.48 & 4.00 & 25.33 & 38.47 & 29.42 & 1.77 \\
\hline 314.00 & 0.31 & 0.43 & 0.70 & 1.58 & 4.83 & 25.58 & 36.37 & 30.21 & 1.78 \\
\hline 315.00 & 0.10 & 0.32 & 0.58 & 1.44 & 5.36 & 28.82 & 33.45 & 29.93 & 1.85 \\
\hline 316.00 & 0.02 & 0.26 & 0.69 & 1.68 & 5.59 & 29.71 & 32.22 & 29.83 & 1.80 \\
\hline 317.00 & 0.11 & 0.50 & 1.12 & 2.64 & 6.97 & 24.30 & 29.72 & 34.63 & 1.85 \\
\hline 318.00 & 0.03 & 0.37 & 1.53 & 6.00 & 11.32 & 22.04 & 25.31 & 33.39 & 1.89 \\
\hline 319.00 & 0.07 & 0.47 & 1.80 & 6.18 & 11.58 & 23.13 & 24.58 & 32.19 & 1.83 \\
\hline 320.00 & 0.80 & 0.73 & 2.21 & 6.78 & 13.37 & 23.29 & 24.33 & 28.49 & 1.83 \\
\hline 321.00 & 0.54 & 0.86 & 3.02 & 8.33 & 15.28 & 25.47 & 23.56 & 22.94 & 1.87 \\
\hline 322.00 & 5.37 & 2.08 & 7.75 & 9.85 & 12.51 & 23.04 & 22.10 & 17.30 & 1.81 \\
\hline 323.00 & 1.22 & 0.92 & 4.17 & 10.02 & 20.82 & 27.52 & 20.32 & 15.02 & 1.82 \\
\hline 324.00 & 11.58 & 4.07 & 6.88 & 11.28 & 17.55 & 19.07 & 15.88 & 13.68 & 1.92 \\
\hline 325.00 & 0.03 & 0.25 & 1.04 & 8.63 & 19.10 & 28.97 & 22.71 & 19.28 & 1.64 \\
\hline 326.00 & 0.94 & 13.65 & 41.98 & 23.06 & 4.18 & 2.93 & 4.54 & 8.71 & \\
\hline 327.00 & 0.18 & 0.44 & 1.23 & 8.94 & 19.52 & 28.72 & 22.10 & 18.89 & 1.53 \\
\hline 328.00 & 0.26 & 0.78 & 1.65 & 9.42 & 19.08 & 27.28 & 22.09 & 19.43 & 1.90 \\
\hline 329.00 & 0.30 & 0.82 & 1.34 & 7.45 & 17.39 & 27.85 & 24.09 & 20.75 & 1.69 \\
\hline 330.00 & 0.63 & 1.03 & 1.34 & 6.21 & 15.23 & 29.66 & 25.44 & 20.46 & 1.69 \\
\hline 331.00 & 1.18 & 1.19 & 1.43 & 5.96 & 15.15 & 28.16 & 26.14 & 20.79 & 1.68 \\
\hline 332.00 & 1.72 & 1.59 & 1.72 & 5.64 & 13.72 & 27.56 & 26.77 & 21.27 & 1.71 \\
\hline 333.00 & 1.27 & 1.40 & 1.99 & 5.59 & 13.62 & 27.67 & 25.52 & 22.95 & 1.77 \\
\hline 334.00 & 0.57 & 0.94 & 2.03 & 5.34 & 12.91 & 26.76 & 26.48 & 24.96 & 1.76 \\
\hline 335.00 & 0.45 & 1.31 & 2.76 & 6.37 & 13.39 & 25.06 & 25.52 & 25.14 & 1.83 \\
\hline 336.00 & 2.04 & 1.85 & 3.22 & 7.65 & 13.57 & 22.81 & 25.61 & 23.26 & 1.73 \\
\hline 337.00 & 1.08 & 1.87 & 2.71 & 7.95 & 15.29 & 22.75 & 23.77 & 24.59 & 1.71 \\
\hline 338.00 & 0.64 & 0.76 & 3.13 & 10.56 & 18.66 & 22.95 & 23.56 & 19.75 & 1.88 \\
\hline 339.00 & 0.12 & 0.45 & 1.35 & 13.55 & 24.31 & 25.92 & 17.67 & 16.62 & \\
\hline 340.00 & 0.01 & 0.17 & 1.42 & 16.27 & 24.05 & 24.93 & 17.85 & 15.29 & 1.80 \\
\hline 341.00 & 0.01 & 0.15 & 1.78 & 16.51 & 23.14 & 26.12 & 16.88 & 15.42 & 1.85 \\
\hline 342.00 & 0.01 & 0.22 & 1.92 & 16.15 & 23.68 & 25.03 & 16.57 & 16.42 & 1.77 \\
\hline 343.00 & 0.01 & 0.16 & 1.40 & 12.43 & 24.17 & 26.09 & 17.33 & 18.42 & 1.73 \\
\hline 344.00 & 0.00 & 0.01 & 0.90 & 9.55 & 21.78 & 27.99 & 20.40 & 19.36 & 1.76 \\
\hline 344.01 & 0.03 & 0.07 & 0.93 & 9.95 & 23.17 & 25.92 & 19.62 & 20.31 & 1.78 \\
\hline 344.02 & 0.25 & 0.06 & 0.75 & 9.63 & 22.57 & 27.06 & 19.20 & 20.47 & \\
\hline 344.03 & 0.02 & 0.08 & 0.90 & 10.20 & 22.40 & 26.73 & 19.46 & 20.19 & \\
\hline 344.04 & 0.01 & 0.06 & 0.83 & 9.89 & 22.94 & 26.63 & 19.15 & 20.49 & \\
\hline 344.05 & 0.02 & 0.06 & 0.93 & 10.47 & 23.87 & 25.93 & 18.96 & 19.75 & \\
\hline 344.06 & 0.01 & 0.08 & 0.94 & 9.86 & 22.50 & 27.59 & 19.02 & 20.02 & \\
\hline 344.07 & 0.00 & 0.09 & 0.96 & 10.18 & 22.35 & 27.11 & 19.24 & 20.07 & \\
\hline 344.08 & 0.01 & 0.06 & 0.92 & 10.06 & 22.98 & 25.83 & 19.86 & 20.27 & \\
\hline 345.00 & 0.00 & 0.12 & 0.78 & 6.71 & 19.38 & 29.70 & 23.65 & 19.66 & \\
\hline 346.00 & 0.57 & 0.26 & 1.30 & 4.95 & 14.19 & 30.42 & 27.39 & 20.92 & 1.76 \\
\hline 347.00 & 1.05 & 0.40 & 1.71 & 5.52 & 12.55 & 28.84 & 27.60 & 22.33 & 1.72 \\
\hline 348.00 & 0.04 & 0.68 & 2.32 & $\begin{array}{c}5.84 \\
(\text { cont. })\end{array}$ & 12.60 & 31.18 & 26.28 & 21.05 & 1.69 \\
\hline
\end{tabular}




\begin{tabular}{|c|c|c|c|c|c|c|c|c|c|}
\hline Serial & $\underline{V C S}$ & $\underline{\mathrm{CS}}$ & $\underline{\mathrm{MS}}$ & $\underline{F S}$ & $\underline{\text { VFS }}$ & CSI & FSI & $\underline{\text { CLAY }}$ & $\underline{\mathrm{BD}}$ \\
\hline 349.00 & 0.78 & 0.96 & 3.78 & 7.91 & 14.20 & 24.33 & 27.52 & 20.52 & 1.74 \\
\hline 350.00 & 1.73 & 0.67 & 2.72 & 9.40 & 15.71 & 21.91 & 26.50 & 21.36 & 1.75 \\
\hline 351.00 & 0.39 & 0.21 & 0.39 & 1.85 & 10.92 & 35.54 & 28.68 & 22.03 & 1.36 \\
\hline 352.00 & 0.12 & 0.19 & 0.36 & 1.76 & 10.57 & 34.75 & 28.79 & 23.46 & 1.52 \\
\hline 353.00 & 0.01 & 0.10 & 0.54 & 1.93 & 7.94 & 31.31 & 32.38 & 25.79 & 1.69 \\
\hline 354.00 & 0.01 & 0.07 & 0.47 & 2.05 & 7.94 & 31.48 & 32.07 & 25.92 & 1.71 \\
\hline 355.00 & 0.05 & 0.09 & 0.55 & 2.74 & 9.89 & 30.81 & 31.50 & 24.37 & 1.75 \\
\hline 356.00 & 0.08 & 0.20 & 0.82 & 4.07 & 13.50 & 30.93 & 26.36 & 24.05 & 1.79 \\
\hline 357.00 & 0.37 & 0.46 & 1.35 & 5.53 & 14.56 & 29.71 & 25.30 & 22.71 & 1.80 \\
\hline 358.00 & 0.22 & 0.26 & 0.88 & 4.13 & 12.50 & 32.48 & 26.39 & 23.15 & 1.73 \\
\hline 359.00 & 2.40 & 0.40 & 1.08 & 4.90 & 12.48 & 24.01 & 33.45 & 21.29 & 1.77 \\
\hline 360.00 & 1.52 & 0.67 & 1.19 & 4.98 & 14.04 & 27.43 & 27.35 & 22.83 & 1.78 \\
\hline 361.00 & 0.17 & 0.89 & 2.87 & 6.17 & 14.68 & 25.52 & 26.50 & 23.20 & 1.81 \\
\hline 362.00 & 0.35 & 0.77 & 2.75 & 7.43 & 15.86 & 25.12 & 25.39 & 22.34 & 1.83 \\
\hline 363.00 & 0.24 & 0.96 & 2.26 & 8.68 & 17.56 & 26.01 & 24.61 & 19.68 & 1.80 \\
\hline 364.00 & 0.46 & 1.60 & 4.43 & 10.33 & 18.22 & 24.04 & 22.01 & 18.91 & 1.92 \\
\hline 365.00 & 0.35 & 0.78 & 2.28 & 10.32 & 20.17 & 25.26 & 22.05 & 18.79 & 1.96 \\
\hline 366.00 & 0.63 & 0.89 & 3.53 & 14.65 & 22.29 & 23.17 & 18.41 & 16.43 & 1.88 \\
\hline 367.00 & 1.71 & 0.25 & 0.85 & 3.85 & 10.47 & 29.23 & 30.23 & 23.42 & 1.35 \\
\hline 368.00 & 0.06 & 0.17 & 0.84 & 4.93 & 12.49 & 29.16 & 29.08 & 23.27 & 1.72 \\
\hline 369.00 & 0.05 & 0.22 & 1.27 & 5.53 & 13.46 & 29.36 & 28.04 & 22.08 & 1.93 \\
\hline 370.00 & 0.03 & 0.24 & 1.14 & 4.02 & 13.81 & 31.40 & 27.45 & 21.92 & \\
\hline 371.00 & 0.55 & 0.24 & 0.81 & 4.28 & 16.07 & 30.72 & 26.13 & 21.20 & 1.85 \\
\hline 372.00 & 0.02 & 0.28 & 1.14 & 4.66 & 15.06 & 30.40 & 25.85 & 22.59 & 1.70 \\
\hline 373.00 & 0.57 & 1.06 & 2.66 & 6.11 & 13.94 & 26.10 & 27.51 & 22.04 & 1.86 \\
\hline 374.00 & 2.08 & 1.97 & 2.94 & 6.03 & 13.16 & 14.70 & 35.63 & 23.49 & \\
\hline 375.00 & 1.13 & 1.47 & 3.25 & 7.35 & 15.43 & 24.09 & 23.99 & 23.31 & 1.89 \\
\hline 376.00 & 4.63 & 0.99 & 2.29 & 6.55 & 13.99 & 24.07 & 24.29 & 23.20 & 1.89 \\
\hline 377.00 & 0.43 & 0.86 & 2.30 & 7.12 & 15.49 & 25.77 & 25.07 & 22.96 & 1.83 \\
\hline 378.00 & 0.23 & 1.30 & 2.52 & 6.22 & 13.74 & 26.07 & 25.57 & 24.35 & 1.81 \\
\hline 379.00 & 0.17 & 0.68 & 1.84 & 5.69 & 14.25 & 26.75 & 25.57 & 25.05 & 1.81 \\
\hline 380.00 & 0.54 & 0.97 & 2.62 & 7.76 & 12.32 & 23.95 & 25.87 & 25.97 & 1.81 \\
\hline 381.00 & 0.03 & 0.02 & 1.55 & 29.93 & 34.74 & 12.18 & 8.70 & 12.85 & \\
\hline 382.00 & 0.20 & 0.22 & 1.89 & 15.29 & 26.36 & 24.92 & 16.39 & 14.73 & \\
\hline 383.00 & 0.28 & 0.47 & 3.56 & 2.74 & 8.81 & 23.14 & 32.95 & 28.05 & \\
\hline
\end{tabular}

Table 1. Table of particle size (in weight percent) and bulk density (in $\left.\mathrm{g} / \mathrm{cm}^{3}\right)$ data for all samples. VCS = very coarse sand $(1-2 \mathrm{~mm}), \mathrm{CS}=$ coarse sand $(0.5-1 \mathrm{~mm}), \mathrm{MS}=$ medium sand $(0.25-0.5 \mathrm{~mm}), F S=$ fine sand $(0.125-0.25 \mathrm{~mm})$, VFS $=$ very fine sand $(0.063-0.125 \mathrm{~mm}), \mathrm{CSI}=$ coarse silt $(16-63 \mathrm{Im})$, FSI $=$ fine silt $(2-16 \mathrm{Im})$, clay $=$ less than 2 Im, $\mathrm{BD}=$ bulk density. 

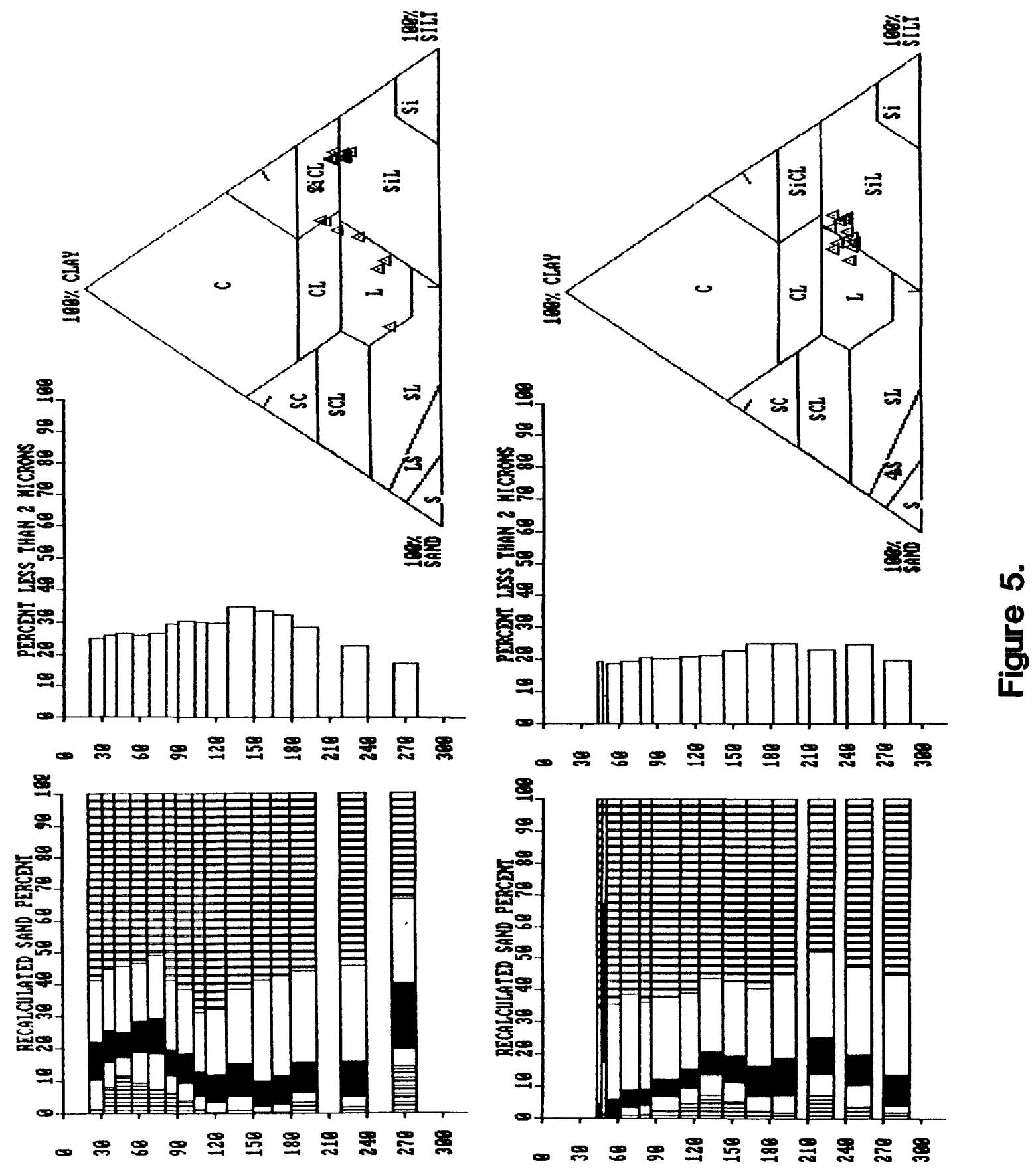

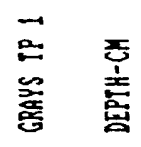

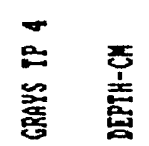



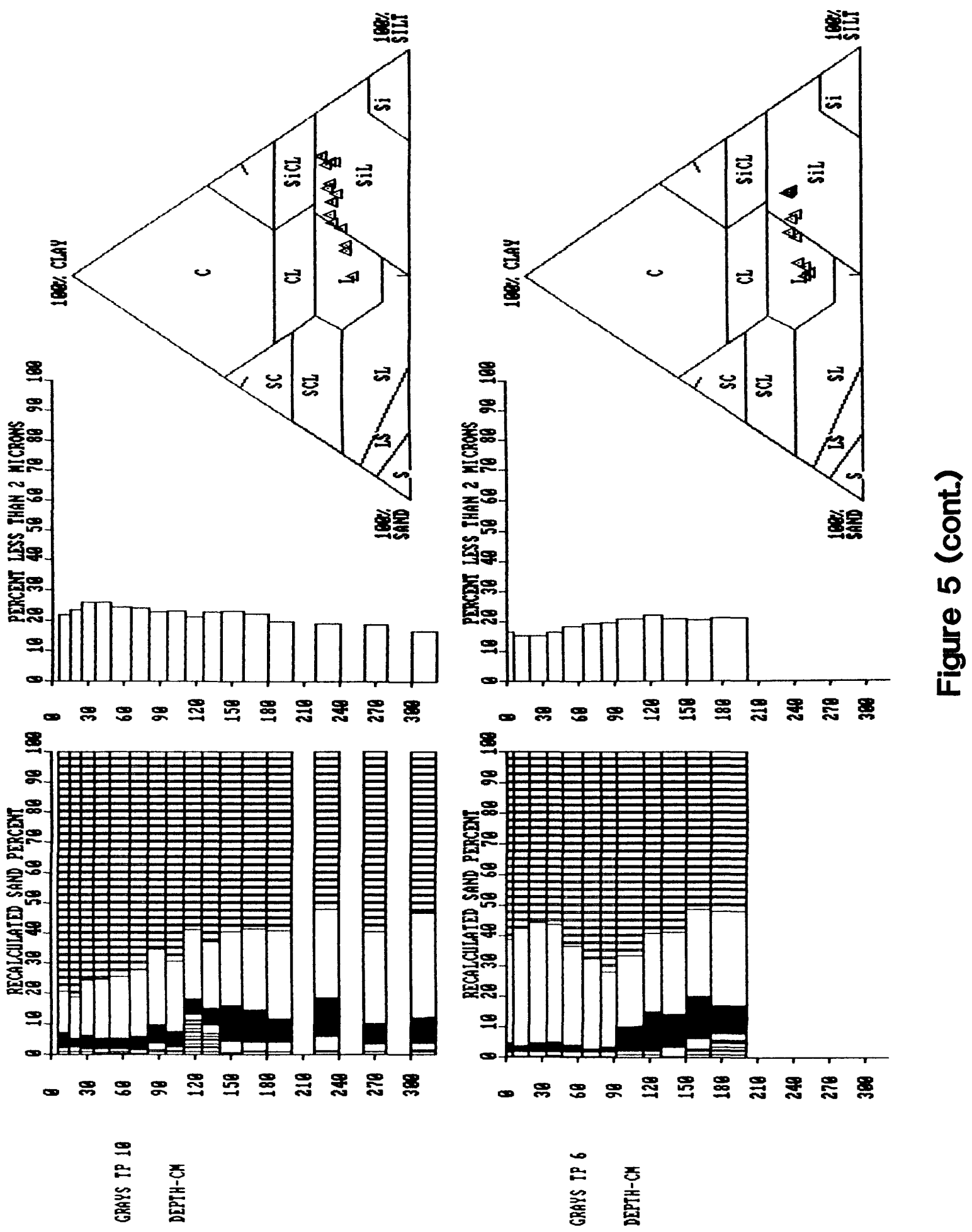


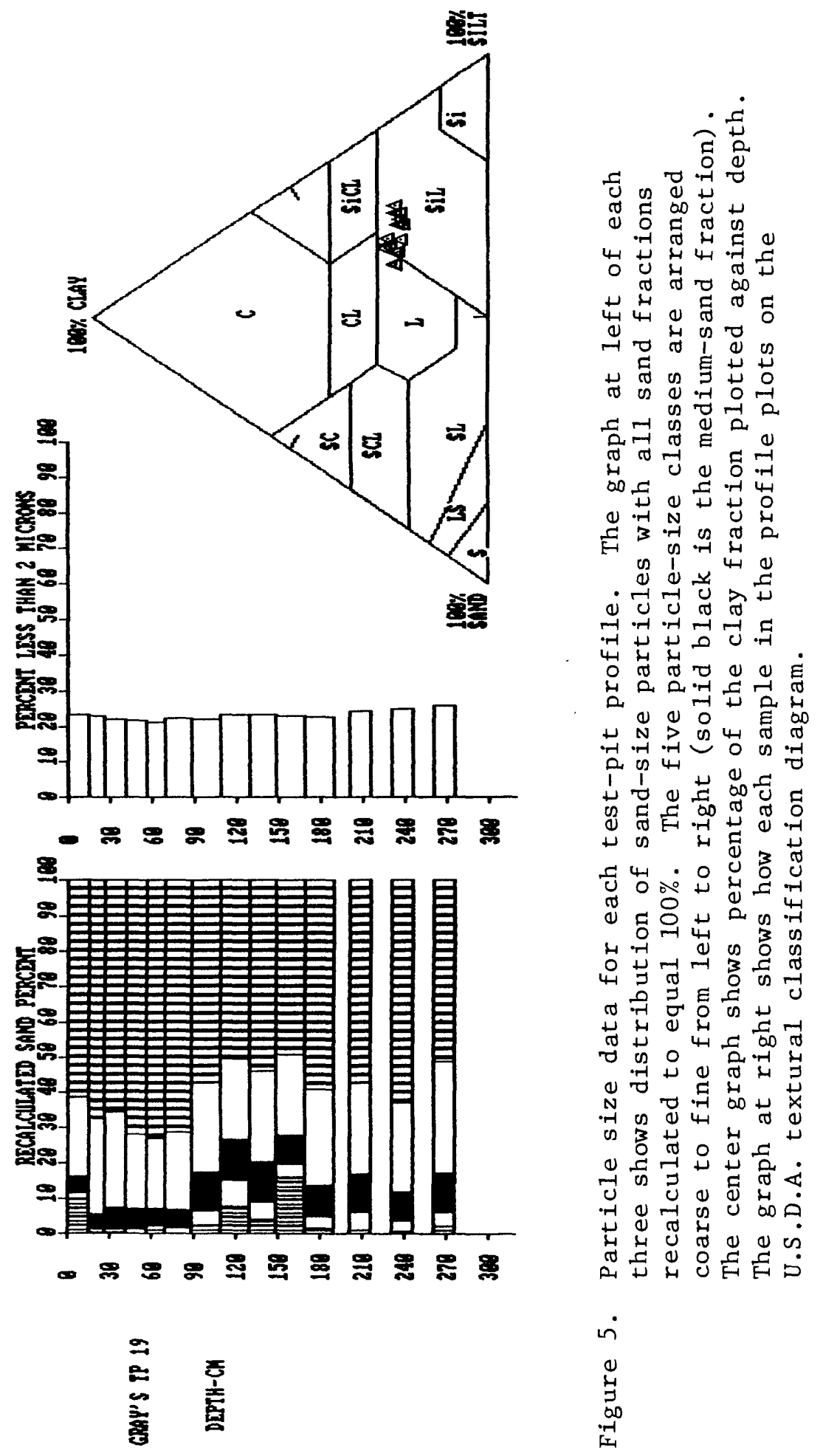


Samples from TP 10 were treated with the CBD procedure described in the methods section and the resulting solutions were analyzed for $\mathrm{Fe}, \mathrm{Si}$, and $\mathrm{Al}$. The CBD treatment dissolves primary and secondary, crystalline and amorphous, iron oxyhyrdroxides and other elements that may be mixed with the oxyhydroxides. Commonly, iron oxyhydroxides occur with amorphous silica and aluminum oxyhydroxides in gel form. These gels are intermediate weathering products and their abundance relative to unweathered material is a measure of weathering intensity. However, it should be emphasized that oxyhydroxides are much more mobile in the soil than particulate clay particles, hence potential exists for contamination by lateral additions (or losses) of these constituents. As a result, accumulation of CBD-liberated elements is not as orderly a process as that of clay accumulation.

CBD-extracted $\mathrm{Fe}_{2} \mathrm{O}_{3}$ data for TP 10 are given in table 2; figure 6 shows depth distributions of clay and $\mathrm{CBD}-\mathrm{Fe}_{2} \mathrm{O}_{3}$. The $\mathrm{Fe}_{2} \mathrm{O}_{3}$ distribution mimics the clay distribution, showing the same bulges corresponding to accumulations in the $B$ horizon and fragipan horizons. Similar clay and Fe depth distributions suggest that the $\mathrm{Fe}$ oxyhydroxides are associated with the finer particle sizes.

X-ray diffraction of TP 10 samples was carried out to ascertain the extent to which weathering has occurred in the clay-size fraction. Emphasis is placed on the clay-size fraction because the high surface area:volume ratio of particles in this size fraction makes them relatively reactive. Results $x$-ray diffraction peak-ratio measurements are given in table 2 , and $x$-ray diffraction patterns are shown in fig. 7 .

A11 samples are dominated by illite (10 A), vermiculite (14 A), and an intermediate, 10 - $14 \mathrm{~A}$ phase (illite/smectite or illite/vermiculite). Lack of peaks in the $17 \mathrm{~A}$ range in glycolated samples indicates that no pure smectite is present; however, some samples show an increased peak at 15 A upon glycolation, indicating that slight swelling of the $14 \mathrm{~A}$ phase is possible. Lack of $14 \mathrm{~A}$ peaks upon heat treatment indicates that there are no appreciable amounts of non-collapsable chlorite-type phases.

Weathering-induced changes in clay mineralogy are seen in the occurrence of kaolinite (7.1 A phases at $350^{\circ}$ ) and $14-15 \mathrm{~A}$ expansion in glycolated samples. Kaolinite occurs in moderate abundances from 80 to $110 \mathrm{~cm}$, and in trace amounts 25 to $80 \mathrm{~cm}$ and 110 to $220 \mathrm{~cm}$, corresponding to areas of low, CBD-extracted silica : aluminum ratios as shown in fig. 8a. Figure $8 \mathrm{~b}$ shows the ratio of $15 \mathrm{~A}$ to $10 \mathrm{~A}$ peak intensities as functions of depth. Low silica in the B horizon, $30-150 \mathrm{~cm}$, corresponds with high $15 \mathrm{~A}: 10$ A ratios, suggesting that silica is being maintained in the expandable phases. The increase in CBD-Al, $120-180 \mathrm{~cm}$, corresponds with a decrease in the $15 \mathrm{~A}$ : $10 \mathrm{~A}$ ratio, suggesting presence of $\mathrm{Al}$ inhibits expansion. Although the processes responsible for these trends cannot be determined in detail without much more study, these data effectively show that the soil profile has undergone appreciable weathering and geochemical reorganization in both the CBD extract and clay-size fraction, especially in the Bt and Btx horizons. 


$\begin{array}{lcccc}\underline{\text { SERIAL }} & \underline{8 F e}_{2} \underline{\mathrm{O}_{3}} & \underline{8 \mathrm{AI}}_{2} \underline{\mathrm{O}}_{3} & \underline{8 \mathrm{SiO}}_{2} & \text { Ratio. } 15 \mathrm{~A}: 10 \mathrm{~A} \\ 351.00 & 2.29 & 0.51 & 0.18 & 1.10 \\ 352.00 & 2.29 & 0.50 & 0.14 & 1.25 \\ 353.00 & 2.72 & 0.44 & 0.06 & 1.00 \\ 354.00 & 2.80 & 0.41 & 0.05 & 1.20 \\ 355.00 & 2.74 & 0.39 & 0.03 & 1.68 \\ 356.00 & 2.96 & 0.40 & 0.05 & 1.56 \\ 357.00 & 2.82 & 0.36 & 0.04 & 1.22 \\ 358.00 & 2.72 & 0.34 & 0.03 & 1.55 \\ 359.00 & 2.56 & 0.32 & 0.04 & 1.43 \\ 360.00 & 2.70 & 0.34 & 0.04 & 1.37 \\ 361.00 & 2.82 & 0.36 & 0.05 & 1.11 \\ 362.00 & 2.92 & 0.37 & 0.06 & 1.10 \\ 363.00 & 2.52 & 0.27 & 0.06 & 1.20 \\ 364.00 & 2.50 & 0.24 & 0.09 & 1.39 \\ 365.00 & 2.47 & 0.22 & 0.09 & 1.36 \\ 366.00 & 2.33 & 0.18 & 0.08 & 1.34\end{array}$

Table 2. Percent $\mathrm{CBD}$-extractable $\mathrm{Fe}_{2} \mathrm{O}_{3}, \mathrm{Al}_{2} \mathrm{O}_{3}$, and $\mathrm{SiO}_{2}$, and ratio of 15 A to 10 A peaks from $x$-ray diffraction pattern of clay fraction, samples from TP 10 . 

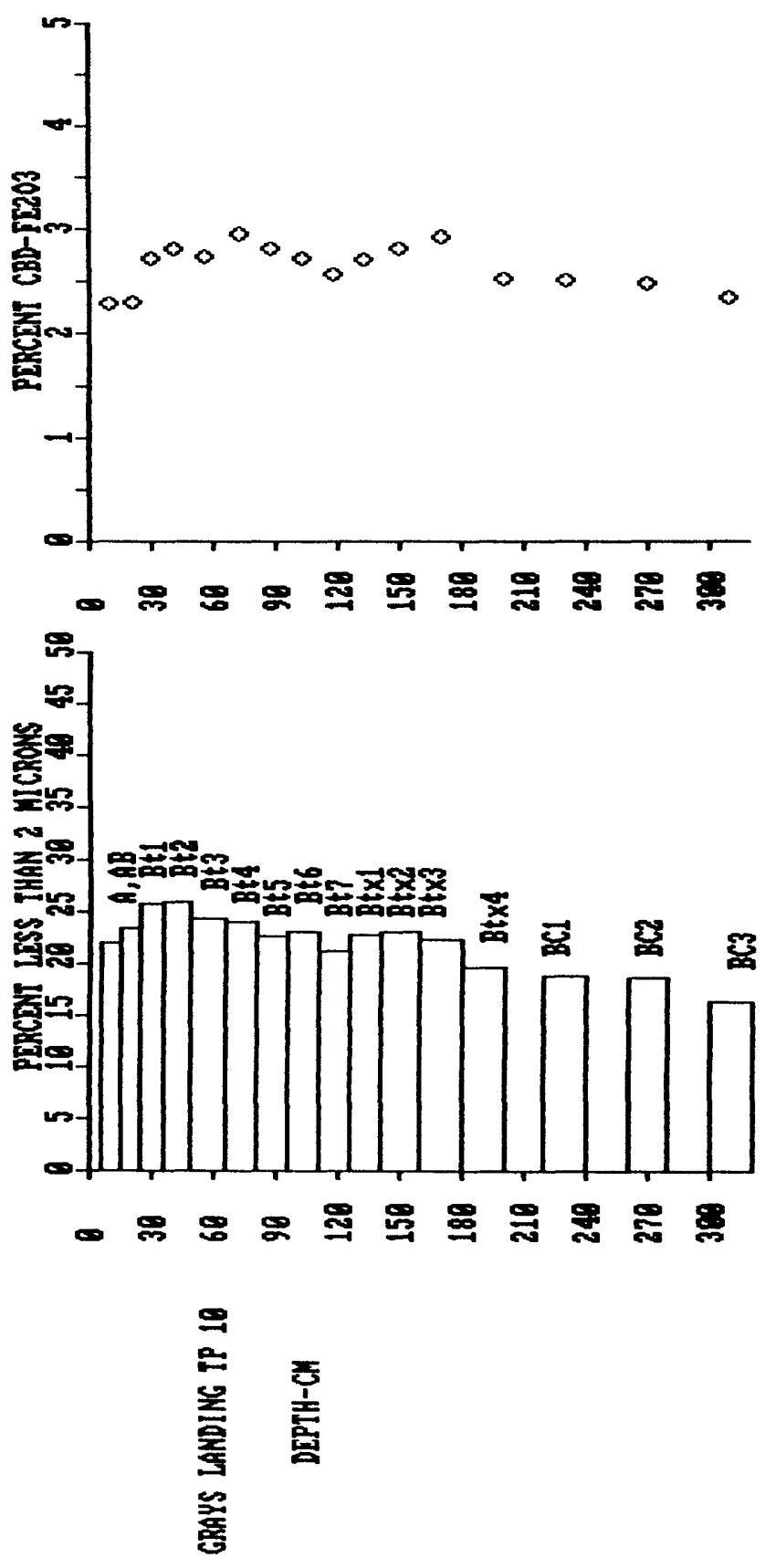

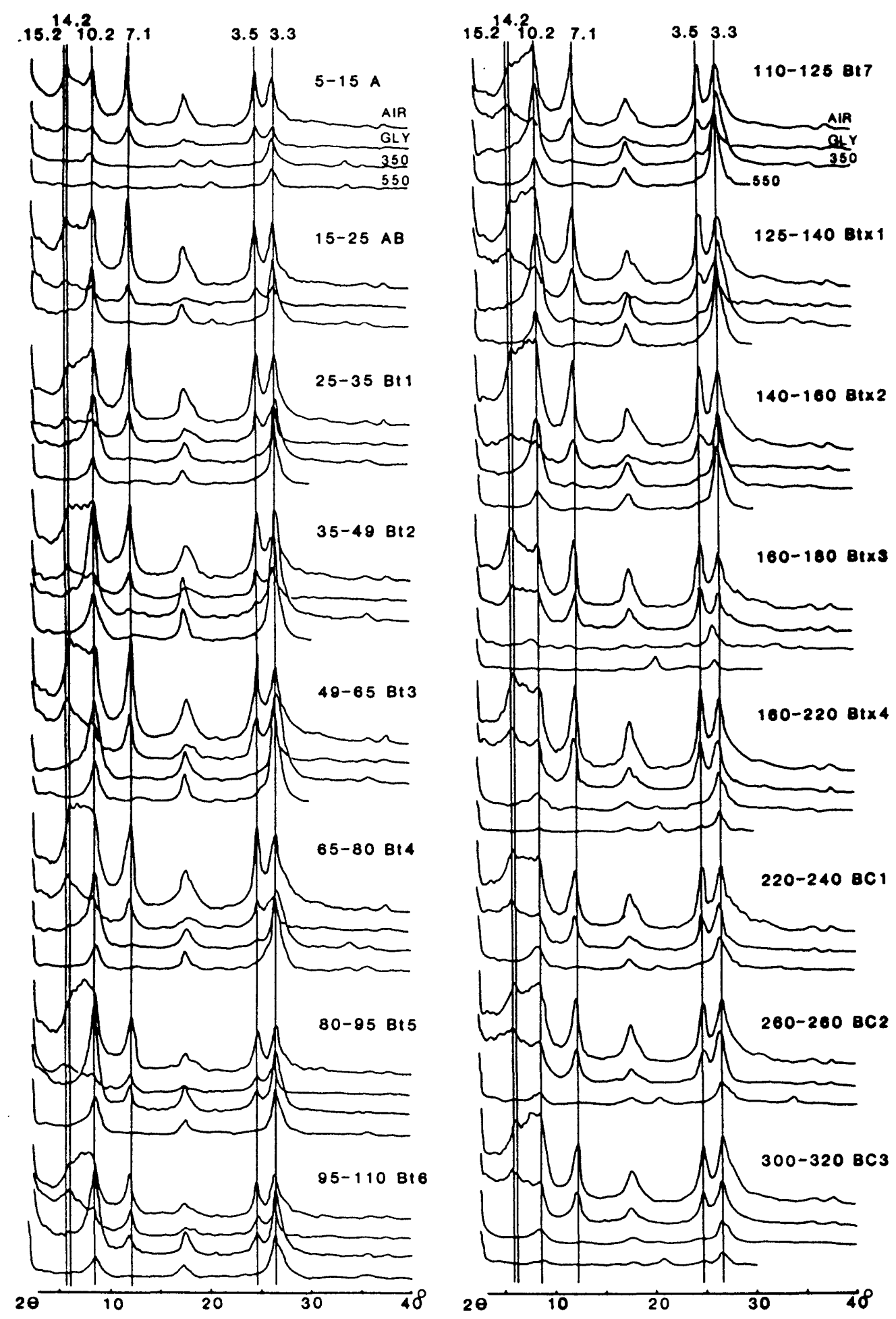

Figure 7. X-ray-diffraction traces for each sample in TP 10. Treatments are: Air = air dry, $\mathrm{Na}^{+}$-saturated; $\mathrm{Gly}=$ ethylene g1ycol solvated; $350=$ heated to $350^{\circ} \mathrm{C} ; 550=$ heated to $550^{\circ} \mathrm{C}$. In a few cases only three traces are plotted due to sample destruction at $550^{\circ} \mathrm{C}$. 


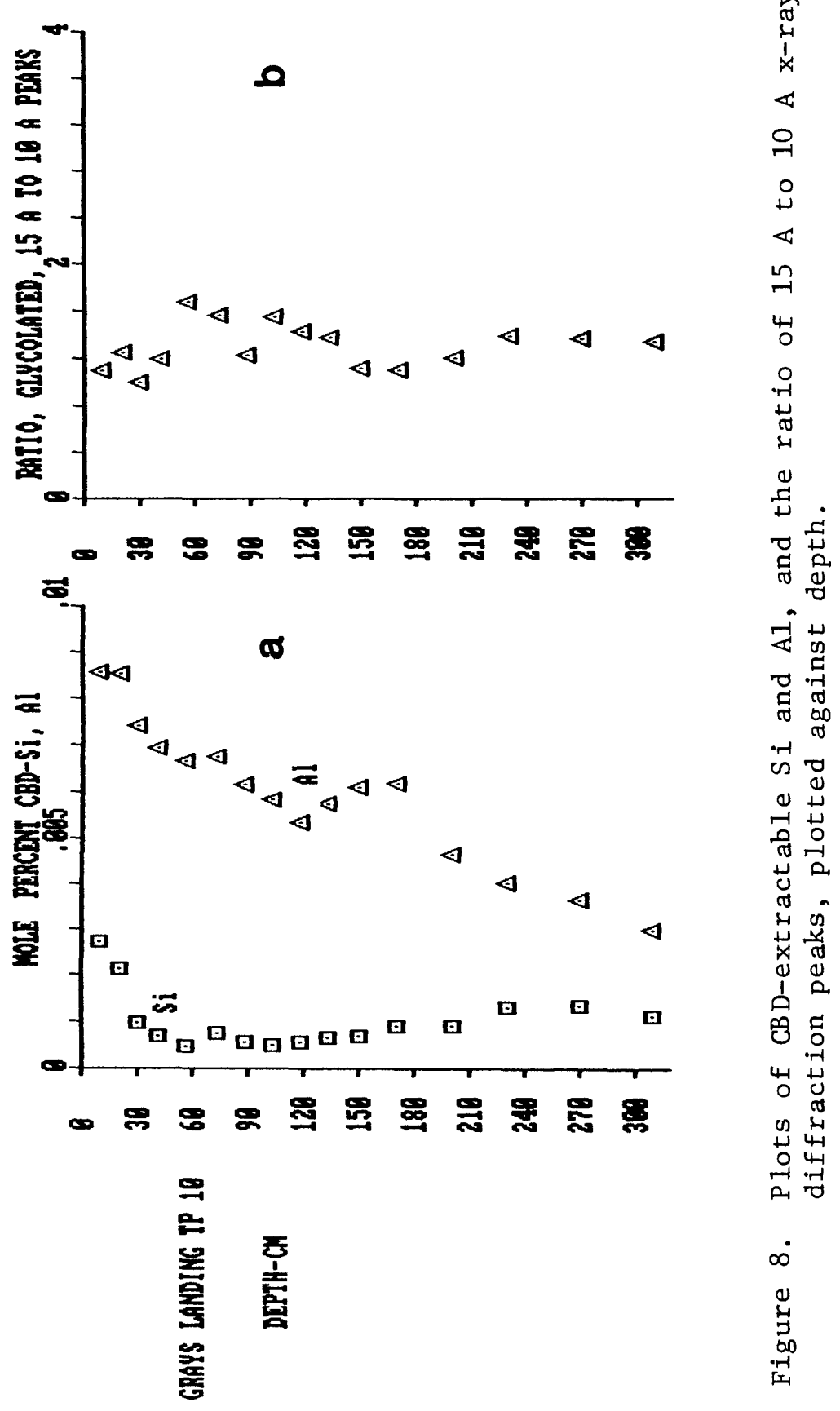




\section{DISCUSSION}

\section{Sedimentology}

Particle-size data for the five soil profiles support the conclusion that the Grays Landing terrace sediment was deposited under slackwater conditions. Figure 9 shows all particle-size data plotted on the top ternary diagram; two other data sets are presented for comparison. All Grays Landing samples plot in the silt to clay portion of the diagram with small amounts of sand. As shown in fig. 5, sand that is present is mostly fine and very fine. Numbered samples in the Grays Landing data indicate samples that are sandier than most. Sample 325 is the well-sorted loamy sand at the top of TP 4, that is probably a very recent flood deposit. Samples 381 and 382 are from TP 25 and TP 21, respectively, and show the sandy nature of sediments below 180 to $200 \mathrm{~cm}$ depth. Sample 324 is a similar basal sandy layer from TP 1.

The other two ternary diagrams in fig. 9 show data from Jacobson (1985) for alluvial and slackwater sediments studied in the Middle Island Creek (MIC) valley in Pleasants County, West Virginia. The MIC slackwater samples have a similar grouping in the silt and clay portion of the diagram; these samples also extend into higher clay contents, largely due to the accumulation of pedogenic clay in these very old soils. In contrast, the MIC alluvial sediments have greater sand contents and greater variability in particle size. These result from the fluvial depositional processes under which a large range of particle sizes can be deposited in environments ranging from current traction in the main channel to suspension in overbank areas. Again, high clay contents in these samples are attributed to intense weathering in some of the samples which range up to greater than $730,000 \mathrm{yr}$ old.

The fine particle sizes and lack of variation in the Grays Landing samples, plus their similarity to known slackwater sediments, strongly suggest that they were deposited under ponded, slackwater conditions.

\section{Soil Chronosequence Dating}

Field evidence indicates that the soils have weathered in place for a considerable length of time. These soils have distinct argillic (Bt) and fragipan (Btx) horizons, strong mottling (sometimes to the point of forming concretions), reddened $B$ horizons, and pedogenic structure extending to depths of $200 \mathrm{~cm}$ and more. Based on field evidence alone, it can be concluded that these soils are certainly older than Holocene and probably older than late Wisconsin.

Laboratory evidence supports and refines this conclusion. Figure 10 is a plot of accumulated clay mass against square root of soil age for the soil chronosequence developed by Jacobson (1985). The accumulated clay mass parameter is calculated by subtracting a background clay content of the parent material (in percent) from that of each horizon. Background clay content is established as that of unweathered $C$ horizon sediment for profiles in which there is a minimum of gradation or layering in the original parent material. The difference, or accumulated clay percent, 


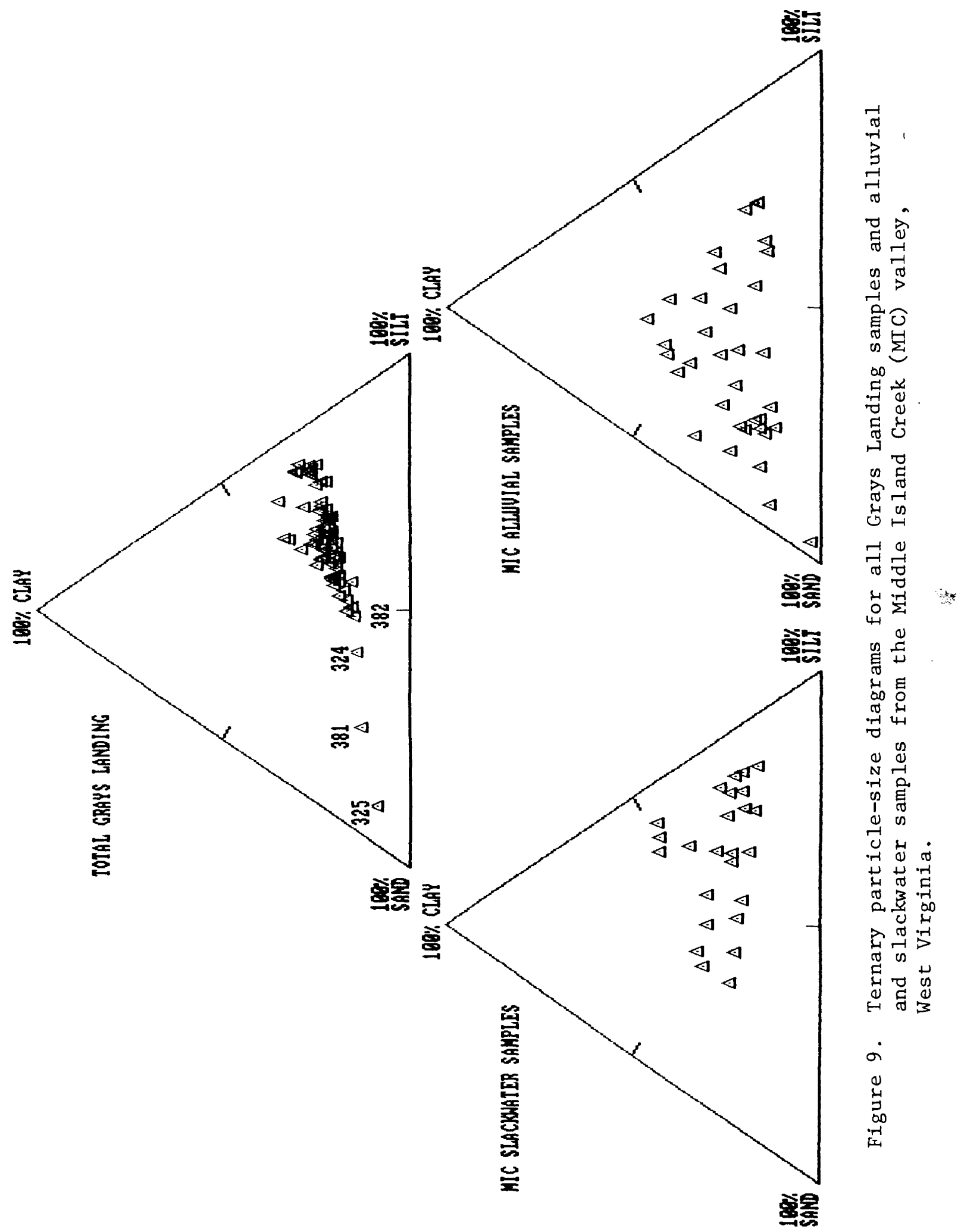


for each horizon is multiplied by the bulk density of the horizon and horizon thickness to give the total accumulated clay mass for each horizon for a unit $\mathrm{cm}^{2}$. When horizon values are summed throughout the profile, a single number results in units of $\mathrm{g} / \mathrm{cm}^{2}$ profile:

$\mathrm{g} / \mathrm{cm}^{2}$ profile $=\Sigma($ (horizons-parent material 8$) *$ thickness $*$ bulk density)

The age of each soil is plotted as the square root of soil age to reflect the parabolic nature of the diffusion processes that govern geochemical processes in soils.

Accumulated clay is plotted for TP 1, TP 4, and TP 10. As discussed above, TP 6 and TP 19 were not suitable for these analyses because of incomplete sampling. TP 1 plots higher than the other two, reflecting the choice of a low background value, a result of the fining-upward trend in that profile. TP 10 and TP 4 plot on the line from 38,000 to 50,000 yr B. P. (TP 1 plots at 84,000 yr B. P.). The two chronosequence points in the vicinity of 60,000 to $80,000 \mathrm{yr}$ B. P. are early Wisconsin-age soils formed on alluvial and slackwater terraces in the Middle Island Creek drainage; the chronosequence points in the vicinity of 10,000 to 15,000 yr B. P. are from a late Wisconsin age terrace along Buffalo Creek in Marion County, West Virginia and a late Wisconsin-age glacial till in Pennsylvania (PA-45-79, from Levine and Ciolkosz, 1983).

The three Grays Landing profiles plot close to the early Wisconsin points and appreciably higher than the late Wisconsin profiles. This, combined with identification of the terrace as a product of slackwater deposition, leads to the conclusion that, of the glacial time slots available for assignment of the ponding event, the early Wisconsin is the most likely.

$\mathrm{CBD}$-extractable $\mathrm{Fe}, \mathrm{Si}$, and $\mathrm{Al}$ and clay mineralogy data provide ancillary support for this conclusion. The depth distributions of $\mathrm{Fe}$, $\mathrm{Si}$, and $\mathrm{Al}$ show that appreciable geochemical activity has occurred in $\mathrm{TP}$ 10, with large amounts of these elements being generated and migrating in the soil profile. X-ray diffraction data show that weathering has been sufficient to produce pedogenic kaolinite and a slightly swelling vermiculitic phase in the $B$ horizon. This degree of pedogenic development was noted by Jacobson (1985) in soils of early Wisconsin age and older but not in those of late Wisconsin and Holocene age. 


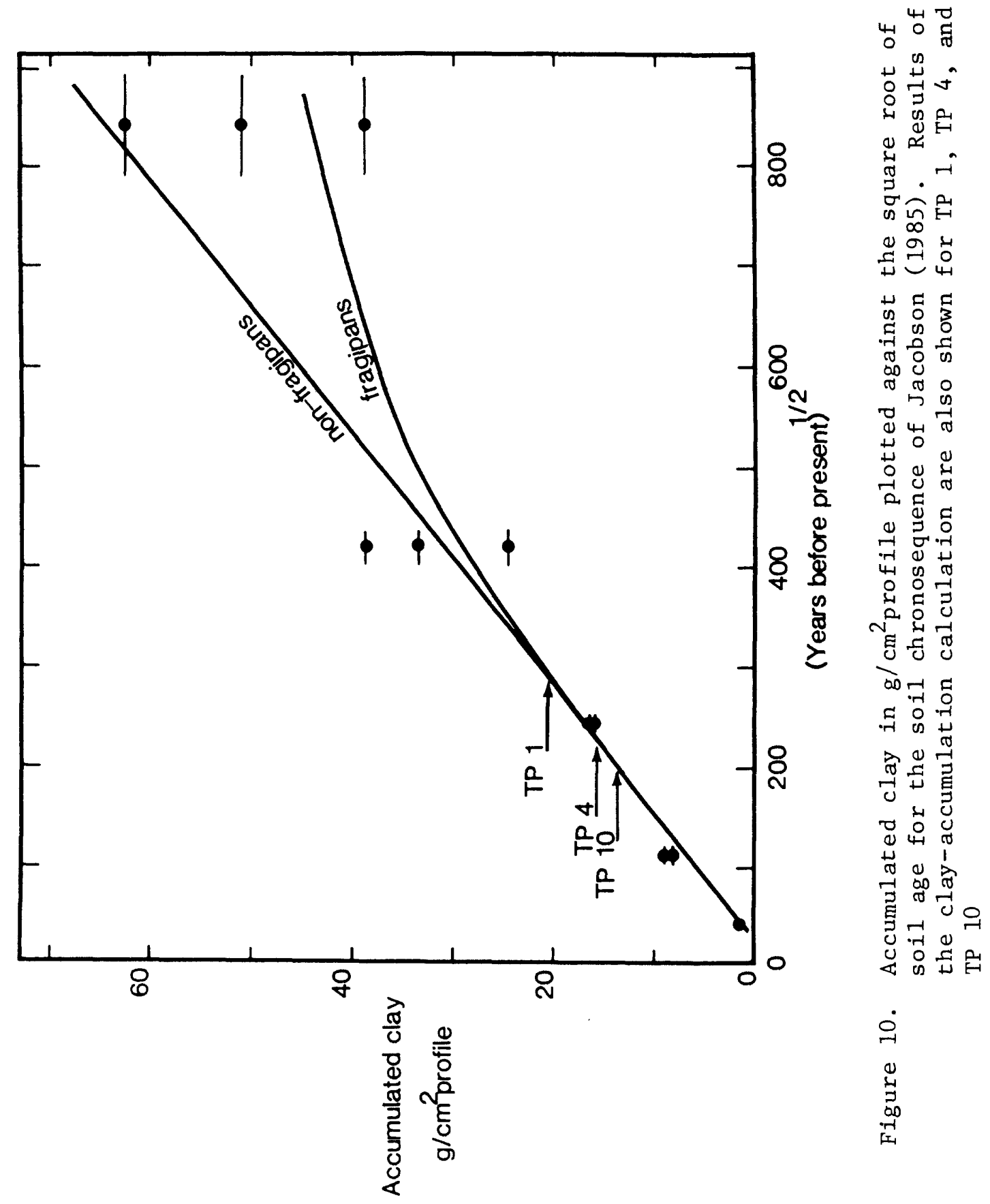




\section{CONCLUSIONS}

Sedimentological data show that the upper 200 to $300 \mathrm{~cm}$ of sediment of the Grays Landing terrace are very similar to known slackwater sediments. These sediments are dominantly silt to clay; the small sand fraction is dominated by very fine sand and fine sand. Variability in the Grays Landing sediments is much less than would be expected if the sediment was deposited as overbank fluvial sediment.

The soil profiles formed on these terrace sediments are old. They have well-developed structure, bisequal profiles with distinct Bt and Btx horizons, reddened colors, and thick profiles (often in excess of $2 \mathrm{~m}$ ). Laboratory data support these observations, showing distinct clay accumulations in the Bt and Btx horizons, production and movement of pedogenic $\mathrm{Fe}$ and $\mathrm{Al}$ oxyhyrdoxides and amorphous $\mathrm{SiO}_{2}$, and production of pedogenic clay-mineral phases. Comparisons to an independently established soil chronosequence for the upper Ohio Valley indicate that the soils have been weathering since the early Wisconsin, or approximately since 60,000 to 80,000 yr B. P. (Thompson and others, 1976). 
References cited:

Adovasio, J. M., Donahue, J., Guilday, J. E., Stuckenrath, R., Gunn, J. D., and Johnson, W. C., 1983, Meadowcroft rock shelter and the peopling of the New World, in, Masters, P. M., and Flemming, N. C., eds., Quaternary coastlines and marine archaeology: New York, Academic Press, p. 413-440.

Birkeland, P. W., 1974, Pedology, weathering, and geomorphological research: New York, Oxford University Press, 285 p.

Carrol1, D., 1970, Clay minerals - a guide to their x-ray identification : Boulder, Co., The Geological Society of America, Special Paper 126, 80 .

Jacobson, R. B., 1985, Spatial and temporal distributions of slope processes in the upper Buffalo Creek basin, Marion County, West Virginia: unpublished Ph.D. dissertation, Baltimore, Md., The Johns Hopkins University, $484 \mathrm{p}$.

Jenny, H., 1941, Factors of soil formation: New York, McGraw-Hìl1.

Levine, E., and Ciolkosz, E. J., 1983, Soil development in till of various ages in northeastern Pennsylvania: Quaternary Research, vol. 19 , p. 85-99.

Mehra, O. P., and Jackson, M. L., 1960, Iron oxide removal from soils and clays by dithionite-citrate system buffered with sodium bicarbonate: Clays and Clay Minerals, vol. 7, p. 317-327.

Munse11, 1975, Munsell soil color charts: Baltimore, Md., Munse11 Color Company, 9 p.

Soil Survey Staff, 1951, Soil survey manual: U.S. Department of Agriculture Handbook no. 18, 503 p.

Thompson, P., Schwarcz, H. P., and Ford, D. C., 1976, Stable isotope geochemistry, geothermometry, and geochronology of speleothems from West Virginia: Geological Society of America Bulletin, v.. 87, p. 1730-1738.

Wentworth, C. K., 1922, A scale of grade and class terms for clastic sediments: Journal of Geology, v. 30, p. 377-392. 